\section{(A) Check for updates}

Cite this: Dalton Trans., 2017, 46, 5250

Received 1st March 2017, Accepted 20th March 2017 DOI: $10.1039 / \mathrm{c} 7 \mathrm{dt} 00752 \mathrm{c}$ rsc.li/dalton

\title{
Hexahalorhenate(Iv) salts of metal oxazolidine nitroxides $\uparrow$
}

\begin{abstract}
Anders H. Pedersen, (D) a Blaise L. Geoghegan, ${ }^{b}$ Gary S. Nichol, (D) a David W. Lupton, ${ }^{c}$ Keith. S. Murray, (D) José Martínez-Lillo, (D)*d Ian A. Gass ${ }^{*^{b}}$ and Euan K. Brechin (D)*a

Eight coordination compounds of formulae $\left[\mathrm{Fe}^{\prime \prime}\left(\mathrm{L}^{*}\right)_{2}\right]\left[\mathrm{Re}^{\mathrm{IV}} \mathrm{Cl}_{6}\right]$ (1a), $\left[\mathrm{Fe}^{I I}\left(\mathrm{~L}^{*}\right)_{2}\right]\left[\mathrm{Re}^{\mathrm{IV}} \mathrm{Br}_{6}\right] \quad(\mathbf{1} \mathbf{b})$, $\left[\mathrm{Co}^{\prime \prime}\left(\mathrm{L}^{*}\right)_{2}\right]\left[\mathrm{Re}^{\mathrm{IV}} \mathrm{Cl}_{6}\right] \cdot \mathrm{CH}_{3} \mathrm{CN}$ (2a), [Co $\left.{ }^{\prime \prime}\left(\mathrm{L}^{*}\right)_{2}\right]\left[\mathrm{Re}^{\mathrm{IV}} \mathrm{Br}_{6}\right] \quad(\mathbf{2 b}), \quad\left[\mathrm{Ni}^{i \prime}\left(\mathrm{L}^{*}\right)\left(\mathrm{CH}_{3} \mathrm{CN}\right)_{3}\right]\left[\mathrm{Re}^{\mathrm{IV}} \mathrm{Cl}_{6}\right] \cdot \mathrm{CH}_{3} \mathrm{CN} \quad(3 \mathbf{a}), \quad\left[\mathrm{Ni}^{\prime \prime}\left(\mathrm{L}^{*}\right)\right.$ $\left.\left(\mathrm{CH}_{3} \mathrm{CN}\right)_{3}\right]\left[\mathrm{Re}^{\mathrm{IV}} \mathrm{Br}_{6}\right] \cdot 3 \mathrm{CH}_{3} \mathrm{CN}(\mathbf{3} \mathbf{b}),\left[\mathrm{Cu}^{\prime \prime}\left(\mathrm{L}^{*}\right)_{2}\right]\left[\mathrm{Re}^{\mathrm{IV}} \mathrm{Cl}_{6}\right](\mathbf{4 a})$ and $\left[\mathrm{Cu}^{\prime \prime}\left(\mathrm{L}^{\circ}\right)_{2}\right]\left[\mathrm{Re}^{\mathrm{IV}} \mathrm{Br}_{6}\right](\mathbf{4 b})$, where $\mathrm{L}^{\circ}$ is the aminoxyl radical chelating ligand, 4,4'-dimethyl-2,2'-di(2-pyridyl)oxazolidine- $N$-oxide, have been synthesised. Structural and magnetic studies reveal metal-radical intramolecular antiferromagnetic interactions in the $\left[M^{\prime \prime}\left(L^{*}\right)_{2}\right]^{2+}$ cations in the iron, cobalt and copper based compounds $(\mathbf{1} \mathbf{a}, \mathbf{1} \mathbf{b}, \mathbf{2} \mathbf{a}, \mathbf{2} \mathbf{b}, \mathbf{4} \mathbf{a}$ and $\mathbf{4} \mathbf{b})$ with the central metal ion low-spin in the case of iron (1a and $\mathbf{1 b}$ ) and a gradual, cobalt based, spin-crossover transition present in $\mathbf{2} \mathbf{a}$ and $\mathbf{2} \mathbf{b}$. The nickel based compounds, $\mathbf{3 a}$ and $\mathbf{3} \mathbf{b}$, were analysed in the dried form ( $\mathbf{3 a}(\mathbf{d r i e d})$ and $\mathbf{3 b}$ (dried)) and directly in acetonitrile $(\mathbf{3 a}$ (solvated) and $\mathbf{3 b}$ (solvated)). Microanalysis and IR spectroscopy on $\mathbf{3 a}$ (dried) and $\mathbf{3 b}$ (dried) suggest that the dried samples are best formulated as $\left[\mathrm{Ni}^{\prime \prime}\left(\mathrm{L}^{*}\right)\right.$ $\left.\left(\mathrm{H}_{2} \mathrm{O}\right)_{3}\right]\left[\mathrm{Re}^{\mathrm{IV}} \mathrm{X}_{6}\right]$, where $\mathrm{X}=\mathrm{Cl}(\mathbf{3 a}$ (dried)) and $\mathrm{Br}$ (3b(dried)). All forms of $\mathbf{3 a}$ and $\mathbf{3 b}$ exhibit cationic metalradical ferromagnetic interactions resulting in $S=3 / 2$ ground states. In addition, 3a(dried) exhibits spincanting behaviour with an ordering temperature of $2.7 \mathrm{~K}$, an open hysteresis loop with a coercive field $H_{\mathrm{C}}=580 \mathrm{Oe}$, and a remanent magnetisation $M_{\mathrm{r}}=0.21 \mu_{\mathrm{B}}$, resulting in a canting angle of $\sim 1.8^{\circ}$. In contrast, $3 \mathrm{~b}$ (dried) shows no spin-canting behaviour; a maximum in $\chi_{M} v s$. $T$ at $T=3 \mathrm{~K}$ suggesting long-range antiferromagnetic ordering. $\mathbf{3 a}$ (solvated) and $\mathbf{3 b}$ (solvated) show no indication of long-range magnetic ordering, unlike $\mathbf{4 a}$ and $\mathbf{4 b}$ where anomalies are evident in the low-temperature magnetic susceptibility measurements.
\end{abstract}

\section{Introduction}

Since the initial discovery of a dodecanuclear Mn molecule exhibiting slow relaxation of its magnetisation in zero field at low temperature, magneto-structural studies of discrete paramagnetic systems have grown exponentially. ${ }^{1-3}$ This research encompasses a wide range of magnetic materials including organic radicals, mono- and multinuclear homometallic transition metal or lanthanide based complexes, as well as heterometallic $3 \mathrm{~d} / 4 \mathrm{f}$ systems. ${ }^{3-6}$ The energy barrier for magnetisation reversal in such systems depends on several factors, but in all cases magnetic

\footnotetext{
${ }^{a}$ EaStCHEM School of Chemistry, The University of Edinburgh, David Brewster Road, EH9 3FJ Edinburgh, Scotland, UK. E-mail: E.Brechin@ed.ac.uk

${ }^{b}$ School of Pharmacy and Biomolecular Sciences, University of Brighton, Brighton BN2 4GJ, UK. E-mail: I.Gass@brighton.ac.uk

${ }^{c}$ School of Chemistry, Monash University, Clayton, Victoria 3800, Australia

${ }^{d}$ Departament de Quimica Inorgànica/Instituto de Ciencia Molecular (ICMol), Universitat de València, C/Catedrático José Beltrán 2, 46980 Paterna (València), Spain.E-mail: F.Jose.Martinez@uv.es

$\dagger$ Electronic supplementary information (ESI) available: Additional structural and magnetic data/figures. CCDC 1534665-1534675. For ESI and crystallographic data in CIF or other electronic format see DOI: 10.1039/c7dt00752c
}

anisotropy is a key parameter. This has led to increased interest in the giant magnetic anisotropy offered by certain $4 \mathrm{f} / 5 \mathrm{f}$ ions with unquenched orbital angular momenta, and selected $4 \mathrm{~d} / 5 \mathrm{~d}$ metal ions possessing considerable spin-orbit coupling. ${ }^{5,7-11}$

The $5 \mathrm{~d}^{3} \mathrm{Re}^{\mathrm{IV}}$ ion is characterised by large magnetic anisotropy originating from second order spin-orbit coupling, with $\lambda \approx 1000 \mathrm{~cm}^{-1}$ for the free ion, often resulting in large values of the axial zero field splitting parameter, $D .^{12,13}$ In addition, the diffuse nature of the $5 \mathrm{~d}$ orbitals gives rise to significant spin delocalisation onto the ligand atoms directly bonded to it, leading to non-negligible intermolecular magnetic exchange interactions, commonly mediated by Re-X... $\mathrm{X}-\mathrm{Re}^{14-19}$ or $\mathrm{Re}-\mathrm{X} \cdots \mathrm{H}_{2} \mathrm{O} \cdots \mathrm{X}-\mathrm{Re}$ contacts. ${ }^{20}$ Extensive research on the hexahalorhenate moiety $\left[\mathrm{Re}^{\mathrm{IV}} \mathrm{X}_{6}\right]^{2-}(\mathrm{X}=\mathrm{F}, \mathrm{Cl}, \mathrm{Br}$ or I) has shown that the magnetic behaviour of the anion in the solid state depends greatly on the nature of the cation employed. The latter include organic radicals, ${ }^{21}$ alkali metals, ${ }^{22}$ ferrocenium, ${ }^{23}$ and the Single-Molecule Magnet (SMM) ' $\mathrm{Mn}_{6}{ }^{2} \cdot{ }^{24,25}$ For example, research conducted on the $\left[\mathrm{Re}^{\mathrm{IV}} \mathrm{I}_{6}\right]^{2-}$ anion with alkali metal cations, $\mathrm{Li}^{+}$to $\mathrm{Cs}^{+}$, illustrated the effect of cation size on the intermolecular Re-I...I-Re interaction, where it was found that the magnetic ordering temperature increased with 


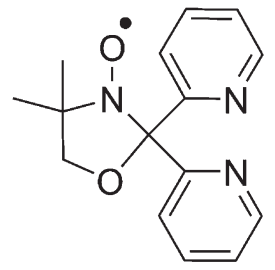

Scheme 1 Molecular structure of 4,4'-dimethyl-2,2'-di(2-pyridyl) oxazolidine- $N$-oxide, $L^{\text {: }}$.

decreasing cation size, ${ }^{22}$ whilst replacing the perchlorate counter ions with $\left[\mathrm{Re}^{\mathrm{IV}} \mathrm{Cl}_{6}\right]^{2-}$ in the $\mathrm{Mn}_{6}{ }^{26-34} \mathrm{SMM}$ led to the energy barrier for magnetisation relaxation increasing by $30 \% .^{24}$

Investigations into the exchange interactions and magnetic properties present in molecule-based magnets containing a coordinated radical, through the 'metal-radical approach', were instigated in the late 1980s and early 1990s. ${ }^{35,36}$ This focused initially on the use of nitroxide-based radicals, resulting in the discovery of the first Single-Chain Magnet (SCM), $\left[\mathrm{Co}^{\mathrm{II}}(\mathrm{hfac})_{2}(\mathrm{NITPhOMe})\right]$, and the ferrimagnetically ordered system $\left\{\mathrm{Mn}^{\mathrm{II}}(\mathrm{hfac})_{2}(\mathrm{~L})\right\}_{n}{ }^{37,38}$ (hfac $=$ hexafluoro-acetylacetonate, NITPhOMe $=4$ '-methoxy-phenyl-4,4,5,5-tetramethylimidazoline-1oxyl-3-oxide and $\mathrm{L}=1,3,5$-tris $\{p$-( $N$-oxy- $N$-tert-butylamino $)$ phenyl $\}$ benzene). Here, the hfac co-ligand was used to increase the Lewis acidity of the central metal ion, enabling the nitroxide $\mathrm{N}-\mathrm{O}$ moiety, a weak Lewis base, to coordinate directly to the metal.

A second approach for coordinating a radical based group directly to the metal ion is to create ligands combining a radical species in close proximity to a conventional ligating group such as bipyridine, imidazole or pyridine. ${ }^{39-41}$ The $\left[\mathrm{M}^{\mathrm{II}}\left(\mathrm{L}^{\circ}\right)_{2}\right]^{2+}$ unit,

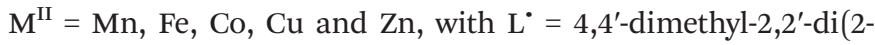
pyridyl)oxazolidine- $N$-oxide (Scheme 1), has been studied over the past decade leading to the discovery of interesting magnetic phenomena such as spin-crossover, ferromagnetic exchange and reductively induced oxidation. ${ }^{41-46}$ Herein we report an extension to these studies with the synthesis and magnetic characterisation of a series of coordination compounds containing both the $\left[\mathrm{M}^{\mathrm{II}}\left(\mathrm{L}^{*}\right)_{2}\right]^{2+}$ cation and the $\left[\mathrm{Re}^{\mathrm{IV}} \mathrm{X}_{6}\right]^{2-}$ anion. When the transition metal in the $\left[\mathrm{M}^{\mathrm{II}}\left(\mathrm{L}^{\circ}\right)_{2}\right]^{2+}$ cation is $\mathrm{Fe}$, Co or $\mathrm{Cu}$ and used in combination with $\left[\mathrm{Re}^{\mathrm{IV}} \mathrm{Cl}_{6}\right]^{2-}$ and $\left[\mathrm{Re}^{\mathrm{IV}} \mathrm{Br}_{6}\right]^{2-}(\mathbf{1 a}, \mathbf{1 b}, \mathbf{2 a}$, 2b, 4a and 4b) we observe predominantly antiferromagnetic metal-radical exchange interactions and typical $\left[\mathrm{Re}^{\mathrm{IV}} \mathrm{X}_{6}\right]^{2-}$ anion behaviour, with a gradual spin-crossover transition present in $\mathbf{2 a}$ and $\mathbf{2} \mathbf{b}$. Using $\mathrm{Ni}$ yields the crystalline products $\left[\mathrm{Ni}^{\mathrm{II}}\left(\mathrm{L}^{\circ}\right)\left(\mathrm{CH}_{3} \mathrm{CN}\right)_{3}\right]\left[\mathrm{Re}^{\mathrm{IV}} \mathrm{Cl}_{6}\right] \cdot \mathrm{CH}_{3} \mathrm{CN}(\mathbf{3 a})$ and $\left[\mathrm{Ni}^{\mathrm{II}}\left(\mathrm{L}^{\circ}\right)\left(\mathrm{CH}_{3} \mathrm{CN}\right)_{3}\right]$ $\left[\mathrm{Re}^{\mathrm{IV}} \mathrm{Br}_{6}\right] \cdot 3 \mathrm{CH}_{3} \mathrm{CN}$ (3b), which exhibit cationic metal-radical ferromagnetic interactions, and intermolecular antiferromagnetic interactions ( $3 \mathbf{b}(\mathbf{d r i e d}))$ or spin-canting (3a(dried)).

\section{Experimental}

\section{Materials and methods}

All chemicals were used as received. Syntheses were carried out under aerobic conditions using $\mathrm{CH}_{3} \mathrm{CN}$ dried over $3 \AA$ molecular sieves. $\left(\mathrm{NBu}_{4}\right)_{2}\left[\mathrm{Re}^{\mathrm{IV}} \mathrm{Cl}_{6}\right]$ and $\left(\mathrm{NBu}_{4}\right)_{2}\left[\mathrm{Re}^{\mathrm{IV}} \mathrm{Br}_{6}\right]$ were prepared as described previously. ${ }^{19,47}$ The neutral radical ligand, 4,4'-dimethyl-2,2'-di(2-pyridyl)oxazolidine- $N$-oxide $\left(\mathrm{L}^{\circ}\right)$, was prepared as per literature methods. ${ }^{42}$ Crystals of all eight compounds were collected and left open to air for use in further analysis. Elemental analyses $(\mathrm{C}, \mathrm{H}, \mathrm{N})$ were performed by MEDAC Ltd. Direct current (dc) magnetic susceptibility measurements on all eight compounds were collected on a Quantum Design MPMS-XL SQUID magnetometer equipped with a $7 \mathrm{~T}$ dc magnet in the temperature range of 2-300 K, under an applied field of $0.1 \mathrm{~T}$. Crystalline samples were powdered, dried, and restrained in gelatine capsules for measurements. Magnetic susceptibility measurements were also carried out on crystalline samples of $\mathbf{3} \mathbf{a}$ and $\mathbf{3} \mathbf{b}$ immersed directly in acetonitrile from 200-2 K under an applied field of $0.1 \mathrm{~T}$ (3a(solvated) and $\mathbf{3 b}$ (solvated)). Diamagnetic corrections were applied using Pascal's constants. ${ }^{48}$ The formula and subsequent molecular weight used in the magnetic measurements were determined from the microanalysis of dried samples. Infrared (IR) spectra from 3800 to $600 \mathrm{~cm}^{-1}$ were recorded on a PerkinElmer Spectrum 65 ATR-IR spectrometer. Powder X-ray diffraction measurements were carried out on a Rigaku Oxford Diffraction SuperNova X-ray diffractometer at $298 \mathrm{~K}$ using a scan step size of $0.086^{\circ}$ at $1^{\circ} \mathrm{s}^{-1}$. Calculated patterns were obtained using Mercury 3.7.

\section{Crystallography}

Data were measured on a Rigaku Oxford Diffraction SuperNova (1a, 1b, 2a, 2a.150 K, 2a.200 K, 2a.250 K, 2b, 3b, 4a, and 4b) and Rigaku Oxford Diffraction XCalibur (3a) X-ray diffractometers using Mo-K $_{\alpha}(\mathbf{1 a}, \mathbf{1 b}, \mathbf{2 a}, \mathbf{2 a} \cdot 150 \mathrm{~K}, 3 \mathbf{3}, 3 \mathbf{b}$ and $4 \mathbf{b})$ or $\mathrm{Cu}-\mathrm{K}_{\alpha}(\mathbf{2 b}$ and $\mathbf{4 a})$ radiation. The crystal temperature was maintained at $120 \mathrm{~K}$ using an Oxford Cryosystems Cryostream 700+ low temperature device for all eight complexes. CrysAlisPro was used for diffractometer control and data processing. Structures were solved with olex2.solve (1a, 1b, 2a, 2a.150 K, $\mathbf{2 a} \cdot 200 \mathrm{~K}, \mathbf{2 a} \cdot 200 \mathrm{~K}, \mathbf{2 b}, \mathbf{3 b}, \mathbf{4 a}$ and $\mathbf{4 b})^{49}$ or ShelXS $(\mathbf{3 a})^{50}$ and refined by full-matrix least-squares on $F$-squared using ShelXL, interfaced through Olex2. ${ }^{51}$ In 1 a $\mathrm{C} 12$ is disordered over two positions with partial occupancies of 0.56 and 0.44 . In $2 \mathrm{a}$ the nitrogen atom associated with $\mathrm{N} 4$ on the acetonitrile solvate is disordered over two positions with partial occupancies of 0.45 and 0.55. In 4a C12 and C14 are disordered over two positions with partial occupancies of 0.49 and 0.51 , and 0.53 and 0.47 . All non-hydrogen atoms were refined anisotropically and hydrogens placed at calculated positions. Crystallographic data, selected bond lengths and angles can be found in Tables S1-S7 and Fig. S1 in the ESI. $\dagger$

CCDC 1534665-1534675.

\section{Synthesis}

$\left[\mathrm{Fe}^{\mathrm{II}}\left(\mathbf{L}^{*}\right)_{2}\right]\left[\mathrm{Re}^{\mathrm{IV}} \mathbf{C l}_{\mathbf{6}}\right] \quad$ (1a). $\quad\left(\mathrm{NBu}_{4}\right)_{2}\left[\mathrm{Re}^{\mathrm{IV}} \mathrm{Cl}_{6}\right] \quad(44.0 \quad \mathrm{mg}$, $0.05 \mathrm{mmol})$ and $\mathrm{Fe}^{\mathrm{II}} \mathrm{Cl}_{2} \cdot 4 \mathrm{H}_{2} \mathrm{O}(9.9 \mathrm{mg}, 0.05 \mathrm{mmol})$ were dissolved in $4 \mathrm{ml} \mathrm{CH}_{3} \mathrm{CN}$, to which 4,4'-dimethyl-2,2'-di(2-pyridyl) oxazolidine- $N$-oxide $\left(\mathrm{L}^{\circ}\right)(13.5 \mathrm{mg}, 0.05 \mathrm{mmol})$ in $2 \mathrm{ml} \mathrm{CH}_{3} \mathrm{CN}$ was added. The resultant solution was left to sit overnight at 
$4{ }^{\circ} \mathrm{C}$ yielding green crystals of 1a suitable for X-ray diffraction (14.7 mg, 59\%). Elemental analysis (\%) calculated (found) for $\mathrm{C}_{30} \mathrm{H}_{32} \mathrm{~N}_{6} \mathrm{O}_{4} \mathrm{Cl}_{6}$ FeRe: C, 36.2 (36.0); H, 3.2 (3.2); N, 8.4 (8.5).

$\left[\mathrm{Fe}^{\mathrm{II}}\left(\mathbf{L}^{\circ}\right)_{2}\right]\left[\mathrm{Re}^{\mathrm{IV}} \mathbf{B r}_{6}\right] \quad$ (1) $) . \quad\left(\mathrm{NBu}_{4}\right)_{2}\left[\mathrm{Re}^{\mathrm{IV}} \mathrm{Br}_{6}\right] \quad(57.5 \quad \mathrm{mg}$, $0.05 \mathrm{mmol})$ and $\mathrm{Fe}^{\mathrm{II}} \mathrm{Cl}_{2} \cdot 4 \mathrm{H}_{2} \mathrm{O}(9.9 \mathrm{mg}, 0.05 \mathrm{mmol})$ were dissolved in $4 \mathrm{ml} \mathrm{CH}_{3} \mathrm{CN}$, to which $\mathrm{L}^{\cdot}(13.5 \mathrm{mg}, 0.05 \mathrm{mmol})$ in $2 \mathrm{ml} \mathrm{CH}_{3} \mathrm{CN}$ was added. Crystals started to form immediately so the solution was filtered and left to stand at room temperature where dark green crystals suitable for X-ray diffraction were collected after 24 hours (20.5 mg, 65\%). Elemental analysis (\%) calculated (found) for $\mathrm{C}_{30} \mathrm{H}_{32} \mathrm{~N}_{6} \mathrm{O}_{4} \mathrm{Br}_{6}$ FeRe: C, 28.6 (29.2); H, 2.6 (2.6); N, 6.7 (7.0).

$\left[\mathrm{Co}^{\mathrm{II}}\left(\mathrm{L}^{\circ}\right)_{2}\right]\left[\mathrm{Re}^{\mathrm{IV}} \mathbf{C l}_{6}\right] \cdot \mathbf{2} \mathbf{C H}_{3} \mathbf{C N}(\mathbf{2 a})$. This was synthesised as per $1 \mathrm{a}$ using $\mathrm{Co}^{\mathrm{II}}\left(\mathrm{NO}_{3}\right)_{2} \cdot 6 \mathrm{H}_{2} \mathrm{O}(14.5 \mathrm{mg}, 0.05 \mathrm{mmol})$ instead of $\mathrm{Fe}^{\mathrm{II}} \mathrm{Cl}_{2} \cdot 4 \mathrm{H}_{2} \mathrm{O}$. Brown crystals suitable for X-ray diffraction were grown overnight at $4{ }^{\circ} \mathrm{C}(13.5 \mathrm{mg}, 50 \%)$. The crystals were collected and left to dry in air and analysed as solvent free. Elemental analysis (\%) calculated (found) for $\mathrm{C}_{30} \mathrm{H}_{32} \mathrm{~N}_{6} \mathrm{O}_{4} \mathrm{Cl}_{6}$ CoRe: C, 36.1 (35.4); H, 3.2 (3.2); N, 8.4 (8.8).

$\left[\mathrm{Co}^{\mathrm{II}}\left(\mathrm{L}^{\circ}\right)_{2}\right]\left[\mathrm{Re}^{\mathrm{IV}} \mathrm{Cl}_{6}\right] \cdot 4 \mathrm{CH}_{3} \mathrm{CN}(2 \mathrm{a} \cdot 150 \mathrm{~K}, 2 \mathrm{a} \cdot 200 \mathrm{~K}, 2 \mathrm{a} \cdot 250 \mathrm{~K})$. This was synthesised as per $2 \mathbf{2 a}$. Elemental analysis (\%) calculated (found) for $\mathrm{C}_{30} \mathrm{H}_{32} \mathrm{~N}_{6} \mathrm{O}_{4} \mathrm{Cl}_{6}$ CoRe: C, 36.1 (35.8); H, 3.2 (3.1); N, 8.4 (7.9).

$\left[\mathbf{C o}^{\mathrm{II}}\left(\mathbf{L}^{\cdot}\right)_{2}\right]\left[\mathbf{R e}^{\mathrm{IV}} \mathbf{B r}_{6}\right]$ (2b). This was synthesised as per $\mathbf{1 b}$ using $\mathrm{Co}^{\mathrm{II}}\left(\mathrm{NO}_{3}\right)_{2} \cdot 6 \mathrm{H}_{2} \mathrm{O}(14.5 \mathrm{mg}, 0.05 \mathrm{mmol})$ instead of $\mathrm{Fe}^{\mathrm{II}} \mathrm{Cl}_{2} \cdot 4 \mathrm{H}_{2} \mathrm{O}$. Dark brown crystals suitable for X-ray diffraction were collected from the solution after 24 hours $(27.2 \mathrm{mg}$, 86\%). Elemental analysis (\%) calculated (found) for $\mathrm{C}_{30} \mathrm{H}_{32} \mathrm{~N}_{6} \mathrm{O}_{4} \mathrm{Br}_{6}$ CoRe: C, 28.5 (28.4); H, 2.6 (2.7); N, 6.6 (7.1).

$\left[\mathrm{Ni}^{\mathrm{II}^{\mathrm{II}}}\left(\mathbf{L}^{\circ}\right)\left(\mathrm{CH}_{3} \mathrm{CN}\right)_{3}\right]\left[\mathrm{Re}^{\mathrm{IV}} \mathbf{C l}_{\mathbf{6}}\right] \cdot \mathrm{CH}_{3} \mathbf{C N}$ (3a). This was synthesised as per 1a using $\mathrm{Ni}^{\mathrm{II}}\left(\mathrm{NO}_{3}\right)_{2} \cdot 6 \mathrm{H}_{2} \mathrm{O}(14.5 \mathrm{mg}, 0.05 \mathrm{mmol})$ instead of $\mathrm{Fe}^{\mathrm{II}} \mathrm{Cl}_{2} \cdot 4 \mathrm{H}_{2} \mathrm{O}$. Large brown crystals suitable for X-ray diffraction were collected from the mother liquor after standing at room temperature overnight ( $8.0 \mathrm{mg}, 18 \%)$. The crystals were then collected, and left to dry in air for further use. Upon inspection of the elemental analyses and IR spectra it is clear that the compound formulates as $\left[\mathrm{Ni}^{\mathrm{II}}\left(\mathrm{L}^{\circ}\right)\left(\mathrm{H}_{2} \mathrm{O}\right)_{3}\right]\left[\mathrm{Re}^{\mathrm{IV}} \mathrm{Cl}_{6}\right]-$ the coordinated acetonitrile molecules being replaced by water molecules when left open to air. Elemental analysis (\%) calculated (found) for $\mathrm{C}_{15} \mathrm{H}_{22} \mathrm{~N}_{3} \mathrm{O}_{5} \mathrm{Cl}_{6} \mathrm{NiRe}$ : C, 23.0 (23.1); $\mathrm{H}$, 2.8 (3.0); N, 5.4 (5.6). IR spectra for $\mathbf{3 a ( d r i e d ) ~ a n d ~} \mathbf{3 a ( s o l v a t e d )}$ are shown in Fig. $\mathrm{S} 2 . \dagger$

$\left[\mathbf{N i}^{i \mathrm{II}}\left(\mathrm{L}^{\circ}\right)\left(\mathrm{CH}_{3} \mathrm{CN}\right)_{3}\right]\left[\mathrm{Re}^{\mathrm{IV}} \mathbf{B r}_{6}\right] \cdot \mathbf{3 C H} \mathbf{C H}_{3} \mathbf{C N}$ (3b). This was synthesised as per $1 \mathbf{b}$ using $\mathrm{Ni}^{\mathrm{II}}\left(\mathrm{NO}_{3}\right)_{2} \cdot 6 \mathrm{H}_{2} \mathrm{O}(14.5 \mathrm{mg}, 0.05 \mathrm{mmol})$ instead of $\mathrm{Fe}^{\mathrm{II}} \mathrm{Cl}_{2} \cdot 4 \mathrm{H}_{2} \mathrm{O}$. Large yellow crystals suitable for X-ray diffraction were collected after standing overnight at room temperature (18 mg, 31\%). Upon inspection of the elemental analysis and IR spectra it is clear that the coordinated acetonitrile molecules are replaced by water molecules when left open to air, and the dried sample formulates as $\left[\mathrm{Ni}^{\mathrm{II}}\left(\mathrm{L}^{\circ}\right)\right.$ $\left.\left(\mathrm{H}_{2} \mathrm{O}\right)_{3}\right]\left[\mathrm{Re}^{\mathrm{IV}} \mathrm{Br}_{6}\right]$. Elemental analysis (\%) calculated (found) for $\mathrm{C}_{15} \mathrm{H}_{22} \mathrm{~N}_{3} \mathrm{O}_{5} \mathrm{Br}_{6}$ NiRe: C, 17.2 (17.5); H, 2.1 (2.3); N, 4.0 (4.2). IR spectra for $\mathbf{3 b}$ (dried) and $\mathbf{3 b}$ (solvated) are shown in Fig. S3. $\dagger$

$\left[\mathbf{C u}^{\mathrm{II}}\left(\mathbf{L}^{\circ}\right)_{2}\right]\left[\mathbf{R e}^{\mathrm{IV}} \mathbf{C l}_{6}\right]$ (4a). This was synthesised as per 1a with $\mathrm{Cu}^{\mathrm{II}}\left(\mathrm{NO}_{3}\right)_{2} \cdot 3 \mathrm{H}_{2} \mathrm{O} \quad(0.05 \mathrm{mmol}, 12 \mathrm{mg})$ used instead of $\mathrm{Fe}^{\mathrm{II}} \mathrm{Cl}_{2} \cdot 4 \mathrm{H}_{2} \mathrm{O}$. Dark green crystals suitable for X-ray diffraction were grown overnight at $4{ }^{\circ} \mathrm{C}(16.8 \mathrm{mg}, 67 \%)$. Elemental analysis (\%) calculated (found) for $\mathrm{C}_{30} \mathrm{H}_{32} \mathrm{~N}_{6} \mathrm{O}_{4} \mathrm{Cl}_{6} \mathrm{CuRe}$ C, 35.9 (35.9); H, 3.2 (3.2); N, 8.4 (8.3).

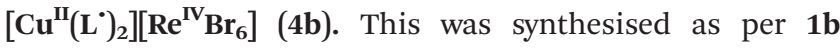
using $\mathrm{Cu}^{\mathrm{II}}\left(\mathrm{NO}_{3}\right)_{2} \cdot 3 \mathrm{H}_{2} \mathrm{O}(12 \mathrm{mg}, 0.05 \mathrm{mmol})$ instead of $\mathrm{Fe}^{\mathrm{II}} \mathrm{Cl}_{2} \cdot 4 \mathrm{H}_{2} \mathrm{O}$. Dark brown crystals suitable for X-ray diffraction were collected from the mother liquor after 4 hours $(32 \mathrm{mg}$, $60 \%$ ). Elemental analysis (\%) calculated (found) for $\mathrm{C}_{30} \mathrm{H}_{32} \mathrm{~N}_{6} \mathrm{O}_{4} \mathrm{Br}_{6}$ CuRe: C, 28.4 (27.8); H, 2.5 (2.6); N, 6.6 (6.8).

\section{Results and discussion}

\section{Structural studies}

Complex 1a (Fig. 1) crystallises in the triclinic space group $P \overline{1}$ with inversion centres on both the $\mathrm{Re}^{\mathrm{IV}}$ and $\mathrm{Fe}^{\mathrm{II}}$ ions. The asymmetric unit contains one half of the $\left[\mathrm{Fe}^{\mathrm{II}}\left(\mathrm{L}^{\circ}\right)_{2}\right]^{2+}$ cation and one half of the $\left[\mathrm{Re}^{\mathrm{IV}} \mathrm{Cl}_{6}\right]^{2-}$ anion. The $\mathrm{Re}^{\mathrm{IV}}$ ion is in a regular octahedral environment coordinated to six chloride ions, with $\mathrm{Re}-\mathrm{Cl}$ bond lengths between 2.3547(8) and 2.3748(9) Å, in accordance with previously published compounds containing the $\left[\mathrm{Re}^{\mathrm{IV}} \mathrm{Cl}_{6}\right]^{2-}$ anion (Table $\left.\mathrm{S} 4 \dagger\right) .{ }^{21,52}$ Two neutral radical ligands are coordinated facially to the $\mathrm{Fe}^{\mathrm{II}}$ ion, bonding in an $\eta^{3}$-fashion through the pyridyl nitrogen atoms and oxygen atoms of the nitroxide (Fig. 1a). This results in a slightly distorted octahedral trans $-\mathrm{N}_{4} \mathrm{O}_{2}$ coordination sphere around the central $\mathrm{Fe}^{\mathrm{II}}$ ion. The $\mathrm{Fe}-\mathrm{N}$ bond distances are 1.984(3) and $1.967(3) \AA$, and the Fe-O bond is $1.872(2) \AA$. The cis angles range between $87.60(12)$ and $92.40(12)^{\circ}$, while the trans angles are generated by the inversion centre resulting in angles of $180^{\circ}$. The nitroxide $\mathrm{N}-\mathrm{O}$ bond length of 1.323 (3) $\AA$ shows the ligand to be in its neutral radical form and not the reduced hydroxylamino anionic form $\left(\mathrm{L}^{-}\right) .{ }^{42}$ The structural features of the cation are in accordance with previously published results on the $\left[\mathrm{Fe}^{\mathrm{II}}\left(\mathrm{L}^{\circ}\right)_{2}\right]^{2+}$ cation containing a central low-spin $\mathrm{Fe}^{\mathrm{II}}$ ion with both ligands in the neutral radical form. ${ }^{42}$ Examination of the crystal packing reveals alternating layers of $\left[\mathrm{Fe}^{\mathrm{II}}\left(\mathrm{L}^{\circ}\right)_{2}\right]^{2+}$ cations and $\left[\mathrm{Re}^{\mathrm{IV}} \mathrm{Cl}_{6}\right]^{2-}$ anions in the crystallographic ac-plane, as seen in Fig. 1b. In the plane of the cations, short $\mathrm{CH} \cdots \pi$ interactions force the $\left[\mathrm{Fe}^{\mathrm{II}}\left(\mathrm{L}^{\circ}\right)_{2}\right]^{2+}$ moieties to pack in chains along the crystallographic $a$-axis. The $\mathrm{CH} \cdots \pi$ distances range from 3.5 to $3.8 \AA$ (Fig. S4 and Table $\mathrm{S} 8 \dagger$ ) between the methyl group on the oxazolidine ring and the centroid of the pyridyl groups. The $\left[\mathrm{Re}^{\mathrm{IV}} \mathrm{Cl}_{6}\right]^{2-}$ ions are surrounded by four cations and are thus well isolated from each other, with the shortest $\mathrm{Cl} \cdots \mathrm{Cl}$ distance being $4.7 \AA$. The $\left[\mathrm{Re}^{\mathrm{IV}} \mathrm{Cl}_{6}\right]^{2-}$ anion interacts with two cations from opposite layers via $\mathrm{Cl} \cdots \pi$ interactions of $3.7 \AA$ (Fig. S4 $\dagger$ ), creating a 1-D network with alternating $\left[\mathrm{Re}^{\mathrm{IV}} \mathrm{Cl}_{6}\right]^{2-}$ and $\left[\mathrm{Fe}^{\mathrm{II}}\left(\mathrm{L}^{\circ}\right)_{2}\right]^{2+}$ ions running diagonally in the unit cell (Fig. 1b, red lines).

Complex $\mathbf{1 b}$ crystallises in the triclinic space group $P \overline{\mathbf{1}}$ and possesses a structure that resembles 1a (Fig. S5†); the most obvious and significant difference being the presence of the hexabromorhenate(Iv) anion instead of the hexachlororhenate(Iv) ion. Inversion centres are located on the $\mathrm{Fe}^{\mathrm{II}}$ and $\mathrm{Re}^{\mathrm{IV}}$ ions with the asymmetric unit containing one half of the 
(a)

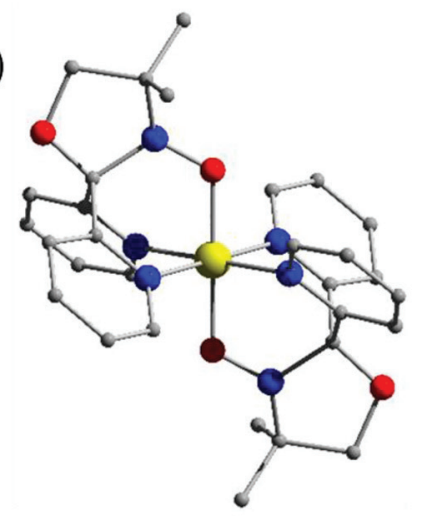

(c)

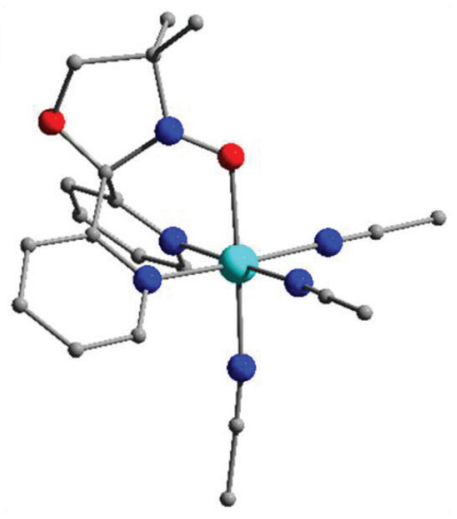

(b)

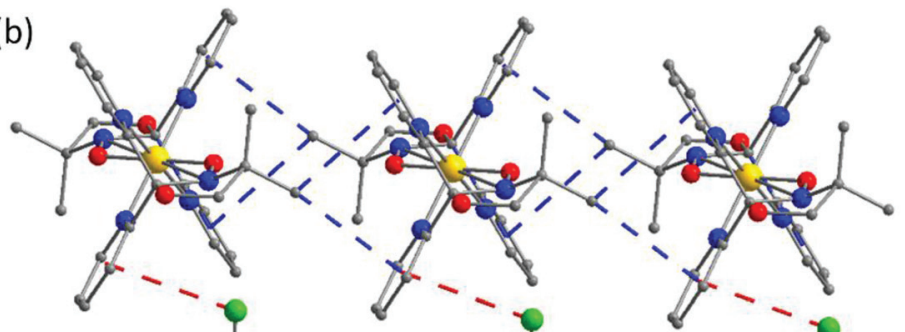

Fig. 1 (a) The structure of the $\left[\mathrm{Fe}^{\prime \prime}\left(\mathrm{L}^{*}\right)_{2}\right]^{2+}$ cation in 1a. (b) The crystal packing of 1a. (c) The $\left[\mathrm{Ni}^{\prime \prime}\left(\mathrm{L}^{\circ}\right)\left(\mathrm{CH}_{3} \mathrm{CN}\right)_{3}\right]^{2+}$ cation present in 3 a and 3 b. Colour code: $\mathrm{Re}$, dark blue; $\mathrm{Ni}$, cyan; $\mathrm{Fe}$, yellow; $\mathrm{Cl}$, green; $\mathrm{O}$, red; $\mathrm{N}$, blue; $\mathrm{C}$, grey. Hydrogen atoms are omitted for clarity. $\mathrm{CH} \cdots \pi$ and $\mathrm{Cl} \cdots \pi$ interactions are indicated by blue and red lines, respectively.

$\left[\mathrm{Fe}^{\mathrm{II}}\left(\mathrm{L}^{\circ}\right)_{2}\right]^{2+}$ cation and one half of the $\left[\mathrm{Re}^{\mathrm{IV}} \mathrm{Br}_{6}\right]^{2-}$ anion. The $\mathrm{Re}^{\mathrm{IV}}$ ion is coordinated to six bromide ions in an octahedral geometry with Re-Br bond lengths of $2.5029(6), 2.5249(6)$ and $2.5132(6) \AA$, similar to that seen in previously published reports on the $\left[\mathrm{Re}^{\mathrm{IV}} \mathrm{Br}_{6}\right]^{2-}$ anion. ${ }^{25,53}$ The bond lengths and angles of the $\left[\mathrm{Fe}^{\mathrm{II}}\left(\mathrm{L}^{\cdot}\right)_{2}\right]^{2+}$ unit are similar to the cation in 1a (Table S4†) suggesting the presence of a central low-spin $\mathrm{Fe}^{\mathrm{II}}$ ion with both ligands in their neutral radical $\left(\mathrm{L}^{\circ}\right)$ form. The packing of $\mathbf{1 b}$ in the crystal is analogous to $1 \mathrm{a}$, with minor deviations originating from the larger $\left[\mathrm{Re}^{\mathrm{IV}} \mathrm{Br}_{6}\right]^{2-}$ ion. The anions are well isolated from each other, as in 1a, with the shortest $\mathrm{Br} \cdots \mathrm{Br}$ distance being $4.6 \AA$ along the crystallographic $a$-axis. The shortest $\mathrm{CH} \cdots \pi$ interaction between the cations is approximately $3.6 \AA$, and the $\mathrm{Br} \cdots \pi$ interactions between the $\left[\mathrm{Fe}^{\mathrm{II}}\left(\mathrm{L}^{\cdot}\right)_{2}\right]^{2+}$ cations and the $\left[\mathrm{Re}^{\mathrm{IV}} \mathrm{Br}_{6}\right]^{2-}$ anions are of the order of $3.8 \AA$ (Fig. S5 and Table S8†).

Complex 2a has similar structural features to $\mathbf{1 a}$ in that it crystallises in the space group $P \overline{1}$ with inversion centres located on both the $\mathrm{Co}^{\mathrm{II}}$ and $\mathrm{Re}^{\mathrm{IV}}$ ions, and the asymmetric unit contains one half of the $\left[\mathrm{Co}^{\mathrm{II}}\left(\mathrm{L}^{*}\right)_{2}\right]^{2+}$ cation and one half of the $\left[\mathrm{Re}^{\mathrm{IV}} \mathrm{Cl}_{6}\right]^{2-}$ anion along with a disordered acetonitrile solvate molecule. This results in an overall formula of $\left[\mathrm{Co}^{\mathrm{II}}\left(\mathrm{L}^{*}\right)_{2}\right]\left[\mathrm{Re}^{\mathrm{IV}} \mathrm{Cl}_{6}\right] \cdot 2 \mathrm{CH}_{3} \mathrm{CN}$ (2a). The bond lengths and bond angles of the $\left[\mathrm{Re}^{\mathrm{IV}} \mathrm{Cl}_{6}\right]^{2-}$ ion are similar to the anion described in 1a (Table S4 $\dagger$ ). The $\left[\mathrm{CO}^{\mathrm{II}}\left(\mathrm{L}^{\circ}\right)_{2}\right]^{2+}$ is structurally similar to the cation described in 1a (Fig. 1a). The $\mathrm{Co}^{\mathrm{II}}$ ion is in a regular, trans $-\mathrm{N}_{4} \mathrm{O}_{2}$ octahedral geometry, coordinated to two $\mathrm{L}^{\circ}$ ligands. The Co-N bond lengths are 1.9251(11) and 1.9556(10) $\AA$, and the Co-O bond length is 1.9103(10) A. The cis bond angles are 85.76(4)-94.24(4) ${ }^{\circ}$ and the trans angles all $180^{\circ}$. The nitroxide $\mathrm{N}-\mathrm{O}$ bond on the ligand is $1.3137(16) \AA$ consistent with the ligand in the neutral radical form $\left(\mathrm{L}^{\circ}\right){ }^{42}$ The packing of $2 \mathrm{a}$ in the crystal is only slightly different from that observed in $\mathbf{1 a}$. The acetonitrile solvent molecules lie in the plane of the anions leading to a different orientation of the $\left[\mathrm{Re}^{\mathrm{IV}} \mathrm{Cl}_{6}\right]^{2-}$ unit, with the shortest $\mathrm{Cl} \cdots \mathrm{Cl}$ interaction being $3.8 \AA$. No $\mathrm{Cl} \cdots \pi$ interactions are observed between the $\left[\mathrm{Co}^{\mathrm{II}}\left(\mathrm{L}^{\circ}\right)_{2}\right]^{2+}$ and $\left[\mathrm{Re}^{\mathrm{IV}} \mathrm{Cl}_{6}\right]^{2-}$ ions. The cations pack as described in $\mathbf{1 a}$, with the shortest $\mathrm{CH} \cdots \pi$ interactions approximately $3.4 \AA$ in length (Fig. S6 and Table S8†).

The bond lengths in the cation in $\mathbf{2 a}$ are shorter than that expected for a low-spin $\mathrm{Co}^{\mathrm{II}}$ ion with an axially elongated pseudo-Jahn-Teller distortion and clearly do not correspond to that of a high-spin $\mathrm{Co}^{\mathrm{II}}$ ion. To clarify the unusual bond lengths contained in the $\left[\mathrm{Co}^{\mathrm{II}}\left(\mathrm{L}^{-}\right)_{2}\right]^{2+}$ cation in $2 \mathrm{a}$, a new set of crystals were grown and X-ray crystallography measurements undertaken on the same single crystal at $150(2 \mathrm{a} \cdot 150 \mathrm{~K}), 200$ $(2 \mathrm{a} \cdot 200 \mathrm{~K})$ and $250 \mathrm{~K}(2 \mathrm{a} \cdot 250 \mathrm{~K})$ (Tables $\mathrm{S} 1, \mathrm{~S} 2$ and S4, Fig. S7 $\dagger$ ). These, however, all crystallised in the monoclinic space group, $P 2_{1} / c$, with an overall formula of $\left[\mathrm{Co}^{\mathrm{II}}\left(\mathrm{L}^{\circ}\right)_{2}\right]$ 
$\left[\mathrm{Re}^{\mathrm{IV}} \mathrm{Cl}_{6}\right] \cdot 4 \mathrm{CH}_{3} \mathrm{CN}$ in contrast to the initial crystal structure which crystallised in the triclinic space group, $P \overline{1}$, and formulated as $\left[\mathrm{Co}^{\mathrm{II}}\left(\mathrm{L}^{\circ}\right)_{2}\right]\left[\mathrm{Re}^{\mathrm{IV}} \mathrm{Cl}_{6}\right] \cdot 2 \mathrm{CH}_{3} \mathrm{CN}$ (2a). An identical synthetic route and crystallising conditions were used for both solvates so we can only conclude that it is very sensitive to external perturbations such as temperature and humidity. Both solvates contain the $\left[\mathrm{Co}^{\mathrm{II}}\left(\mathrm{L}^{*}\right)_{2}\right]^{2+}$ cation and the $\left[\mathrm{Re}^{\mathrm{IV}} \mathrm{Cl}_{6}\right]^{2-}$ anion and differ only in their intermolecular arrangement in the solid state driven mainly by the differing degrees of solvation.

The variable temperature study on $2 \mathrm{a} \cdot 150 \mathrm{~K}, 2 \mathrm{a} \cdot 200 \mathrm{~K}$ and 2a.250 K showed evidence of spin-crossover behaviour: an axially elongated pseudo-Jahn-Teller distortion of the low-spin $\mathrm{Co}^{\mathrm{II}}$ ion was observed at $150 \mathrm{~K}$ which diminished as the temperature was increased (Table S4 and Fig. S7 $\dagger$ ). This suggests a gradual, thermally induced, spin transition between the lowspin and high-spin states of the central $\mathrm{Co}^{\mathrm{II}}$ ion. A comparison of the bond lengths in $2 \mathbf{a}, 2 \mathbf{a} \cdot 150 \mathrm{~K}, 2 \mathbf{a} \cdot 200 \mathrm{~K}$ and $2 \mathbf{2} \cdot 250 \mathrm{~K}$ with similar species can be found in Table S9.†

The bond lengths and angles of the $\left[\mathrm{Re}^{\mathrm{IV}} \mathrm{Cl}_{6}\right]^{2-}$ anion in $2 \mathbf{a} \cdot 150 \mathrm{~K}, 2 \mathbf{a} \cdot 200 \mathrm{~K}, 2 \mathbf{a} \cdot 250 \mathrm{~K}$ are similar to those described in 1a and 2a. The crystal packing is similar in $2 \mathbf{a} \cdot 150 \mathrm{~K}, \mathbf{2 a} \cdot 200 \mathrm{~K}$ and $2 \mathrm{a} \cdot 250 \mathrm{~K}$ with alternate layers of the $\left[\mathrm{Co}^{\mathrm{II}}\left(\mathrm{L}^{\circ}\right)_{2}\right]^{2+}$ cations and the $\left[\mathrm{Re}^{\mathrm{IV}} \mathrm{Cl}_{6}\right]^{2-}$ anions (Fig. S8†). There is no indication of any significant $\mathrm{CH} \cdots \pi$ or $\mathrm{Cl} \cdots \mathrm{Cl}$ intermolecular interactions and the shortest $\mathrm{Cl} \cdots \mathrm{Cl}$ distance is $6.455 \AA$ in $2 \mathrm{a} \cdot 150 \mathrm{~K}, 6.572 \AA$ in $2 \mathbf{a} \cdot 200 \mathrm{~K}$ and $6.715 \AA$ in $2 \mathbf{2} \cdot 250 \mathrm{~K}$ (Table S8†). A comparison of the intermolecular packing in both solvates and their relation to any magnetic properties (vide infra) is rendered moot by the fact that the microanalysis of both solvates suggests that they coalesce upon drying into the same material, namely, $\left[\mathrm{Co}^{\mathrm{II}}\left(\mathrm{L}^{\circ}\right)_{2}\right]\left[\mathrm{Re}^{\mathrm{IV}} \mathrm{Cl}_{6}\right]$.

Complex 2b (Fig. S9†) crystallises in the triclinic space group $P \overline{1}$ with inversion centres located on both the $\mathrm{Co}^{\mathrm{II}}$ and $\mathrm{Re}^{\mathrm{IV}}$ ions; subsequently the asymmetric unit contains one half of the $\left[\mathrm{Co}^{\mathrm{II}}\left(\mathrm{L}^{\circ}\right)_{2}\right]^{2+}$ cation and one half of the $\left[\mathrm{Re}^{\mathrm{IV}} \mathrm{Br}_{6}\right]^{2-}$ anion. The geometrical parameters of the $\left[\mathrm{Re}^{\mathrm{IV}} \mathrm{Br}_{6}\right]^{2-}$ anion are analogous to that described in $\mathbf{1 b}$ (Table $\mathrm{S} 5 \dagger$ ). The $\mathrm{Co}^{\mathrm{II}}$ ion is in a distorted, trans $-\mathrm{N}_{4} \mathrm{O}_{2}$ octahedral geometry, coordinated to two $\mathrm{L}^{*}$ ligands. The $\mathrm{Co}-\mathrm{N}$ bond lengths are 1.963(4) and 1.976(4) $\mathrm{A}$, and the Co-O bond length is 2.092(4) $\AA$. The cis bond angles range from $87.98(17)-92.02(17)^{\circ}$ and the trans angles all $180^{\circ}$. The $\mathrm{N}-\mathrm{O}$ bond on the ligand is 1.269(6) $\AA$ which confirms the neutral radical $\left(\mathrm{L}^{\circ}\right)$ form of the ligand. Bond lengths and angles suggest a central low-spin $\mathrm{Co}^{\mathrm{II}}$ ion showing an axially elongated pseudo Jahn-Teller distortion, consistent with previously reported studies on the $\left[\mathrm{Co}^{\mathrm{II}}\left(\mathrm{L}^{\circ}\right)_{2}\right]^{2+}$ cation (Table S9 $\dagger$ ). ${ }^{43}$ The packing of $\left[\mathrm{Co}^{\mathrm{II}}\left(\mathrm{L}^{*}\right)_{2}\right]\left[\mathrm{Re}^{\mathrm{IV}} \mathrm{Br}_{6}\right]$ in the crystal is identical to that described for $\mathbf{1} \mathbf{b}$. The shortest $\mathrm{CH} \cdots \pi$ interactions between the cations are ca. 3.6 and $3.7 \AA$, and the $\mathrm{Br} \cdots \mathrm{Br}$ interactions approximately $4.6 \AA$. The $\mathrm{Br} \cdots \pi$ interactions between the $\left[\mathrm{Co}^{\mathrm{II}}\left(\mathrm{L}^{-}\right)_{2}\right]^{2+}$ cations and the $\left[\mathrm{Re}^{\mathrm{IV}} \mathrm{Br}_{6}\right]^{2-}$ ions are $3.8 \AA$ A (Fig. S9 and Table S8†).

Complex 3a (Fig. 2) crystallises in the orthorhombic space group $\mathrm{Pbca}$ with the asymmetric unit containing a single $\left[\mathrm{Ni}^{\mathrm{II}}(\mathrm{L} \cdot)\left(\mathrm{CH}_{3} \mathrm{CN}\right)_{3}\right]^{2+}$ cation, the $\left[\mathrm{Re}^{\mathrm{IV}} \mathrm{Cl}_{6}\right]^{2-}$ anion and one acetonitrile solvate molecule. The geometrical parameters of the $\left[\mathrm{Re}^{\mathrm{IV}} \mathrm{Cl}_{6}\right]^{2-}$ ion are similar to those described for $\mathbf{1 a}$ and $\mathbf{2 a}$ (Tables $\mathrm{S} 4$ and $\mathrm{S} 6 \dagger$ ). The $\mathrm{Ni}^{\mathrm{II}}$ ion is atypically coordinated to one tridentate, facially capping $\mathrm{L}^{*}$ ligand, not two as in the other complexes described in this paper, and all other previously published results (Fig. 1c). ${ }^{41-43,45}$ The coordination sphere of the $\mathrm{Ni}^{\mathrm{II}}$ ion is completed by three acetonitrile molecules, creating a slightly distorted octahedral environment around the metal ion with cis angles varying in the range 86.1(17)-93.9(17) ${ }^{\circ}$, the most acute trans angle being $176.19(18)^{\circ}$. The Ni-N bond lengths are 2.068(4) and 2.058(4) $\AA$, with the $\mathrm{Ni}-\mathrm{O}$ distance being 2.073(4) $\AA$. The $\mathrm{N}-\mathrm{O}$ bond length of 1.271 (6) $\AA$ shows the ligand again to be in the neutral radical state $\mathrm{L}^{\circ}{ }^{42}$ The acetonitrile molecules are coordinated to the nickel(II) ion with $\mathrm{Ni}-\mathrm{N}$ bond lengths of 2.071(5), 2.058(5) and 2.037(5) $\AA$, which correlates with the previously published values. ${ }^{54}$ In the crystal the $\left[\mathrm{Re}^{\mathrm{IV}} \mathrm{Cl}_{6}\right]^{2-}$ anions are well isolated from each other, being 'encapsulated' by four cations, resulting in a short $\mathrm{Cl} \cdots \mathrm{Cl}$ distance of $4.55 \AA$ along the crystallographic $a$-axis (Fig. 2a). Short $\mathrm{CH}^{\cdots} \cdots \pi$ interactions of 3.6 and $3.8 \AA$ between the methyl group on the radical ligand and pyridyl rings of the neighbouring cation create a 1-D network travelling along the crystallographic $a$-axis (Fig. S10 and Table S8 $†$ ). In the crystallographic $a b$ plane, chains of cations order in layers separated by $\left[\mathrm{Re}^{\mathrm{IV}} \mathrm{Cl}_{6}\right]^{2-}$ ions (Fig. 2a). The acetonitrile molecule of crystallisation is sandwiched between two $\left[\mathrm{Ni}^{\mathrm{II}}\left(\mathrm{L}^{\circ}\right)\left(\mathrm{CH}_{3} \mathrm{CN}\right)_{3}\right]^{2+}$ cations in the $a b$ plane.

Complex $\mathbf{3} \mathbf{b}$ crystallises in the monoclinic space group $P 2_{1} / c$. The asymmetric unit contains a $\left[\mathrm{Ni}^{\mathrm{II}}\left(\mathrm{L}^{\circ}\right)\left(\mathrm{CH}_{3} \mathrm{CN}\right)_{3}\right]^{2+}$ cation, one $\left[\mathrm{Re}^{\mathrm{IV}} \mathrm{Br}_{6}\right]^{2-}$ anion and three solvent acetonitrile molecules. The structure of the $\left[\mathrm{Ni}^{\mathrm{II}}\left(\mathrm{L}^{\circ}\right)\left(\mathrm{CH}_{3} \mathrm{CN}\right)_{3}\right]^{2+}$ cation is identical to the one presented in $\mathbf{3 a}$, and the $\left[\mathrm{Re}^{\mathrm{IV}} \mathrm{Br}_{6}\right]^{2-}$ anion is as described in $\mathbf{1 b}$ (Fig. 1c). The sole $\mathrm{L}^{\cdot}$ ligand on the cation has close contacts through the methyl groups to two other ligands' pyridyl moieties, creating a 1-D zigzag structure along the crystallographic $a$-axis, as illustrated in Fig. $2 \mathrm{~b}$ and $511 . \dagger$ The $\mathrm{CH} \cdots \pi$ interactions between the methyl groups and the two nearest cations are 3.5 and $3.8 \AA$, which imposes an alternating chain motif. In each chain the ligands are facing 'inwards' and the coordinated acetonitrile molecules are facing 'outwards'. The $\left[\mathrm{Re}^{\mathrm{IV}} \mathrm{Br}_{6}\right]^{2-}$ ions sit in the plane of the $\mathrm{Ni}^{\mathrm{II}}$ ions between two neighbouring cations. The anions are isolated from each other with a short $\mathrm{Br} \cdots \mathrm{Br}$ distance of $3.9 \AA$ along the direction of the crystallographic $c$-axis, creating a 1D network (Table S8 and Fig. S11 $\dagger$ ). The acetonitrile solvent molecules are positioned above and below the plane of the cations (Fig. 2c). Although we have presented structural information on $\mathbf{3 b}$ in the monoclinic space group $P 2_{1} / c$ above, it must be noted that an alternative solvate is also possible containing a single solvate acetonitrile per formula unit. This crystallises in the monoclinic space group $C 2 / c$ and is formulated as $\left[\mathrm{Ni}^{\mathrm{II}}\left(\mathrm{L}^{\circ}\right)\right.$ $\left.\left(\mathrm{CH}_{3} \mathrm{CN}\right)_{3}\right]\left[\mathrm{Re}^{\mathrm{IV}} \mathrm{Br}_{6}\right] \cdot \mathrm{CH}_{3} \mathrm{CN}$. The crystal structures, their intermolecular interactions and subsequent magnetic measurements (vide infra) of both solvates are similar so only that of the $P 2_{1} / c$ solvate has been reported here. 
(a)

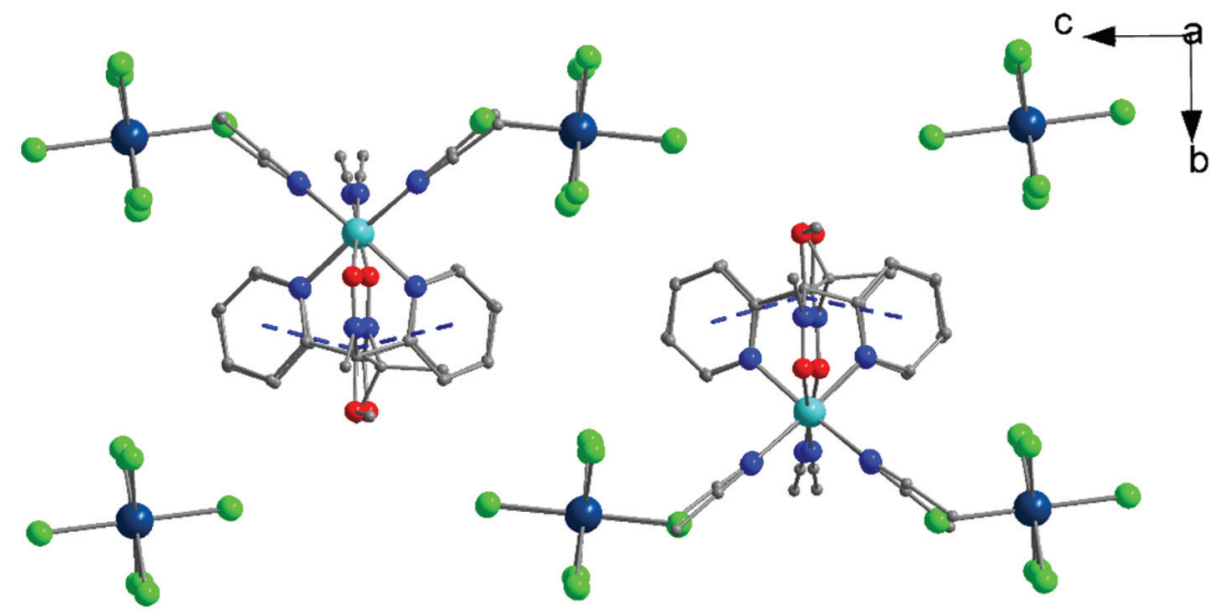

(b)

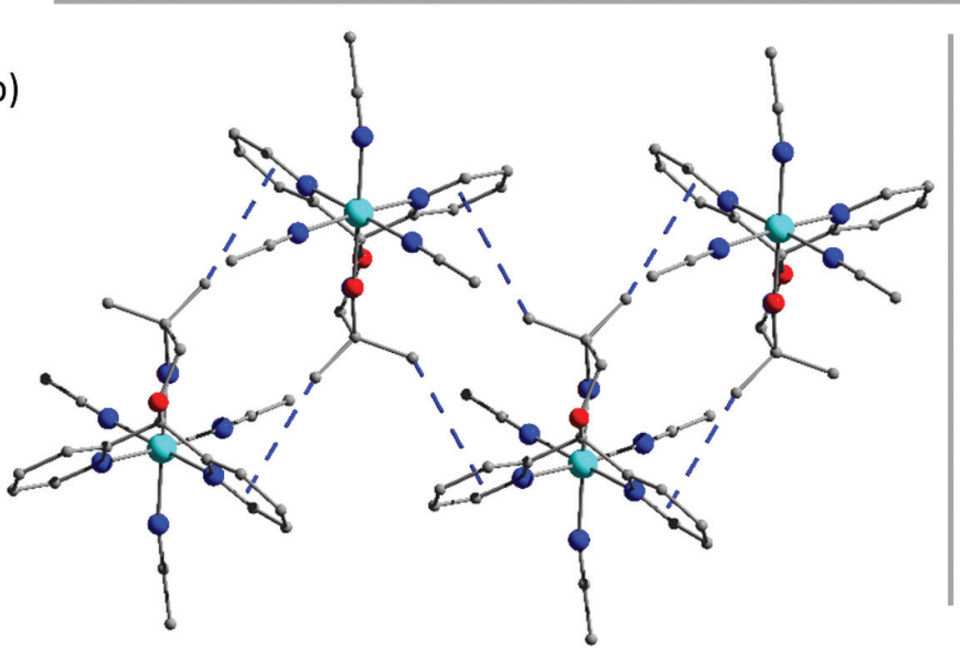

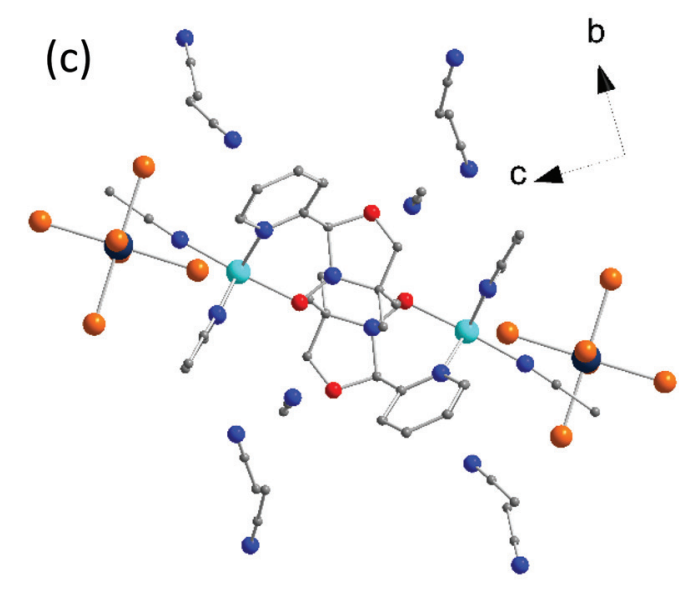

Fig. 2 The packing of 3a viewed down the crystallographic a-axis. (b) The intermolecular interactions between the cations in $3 \mathrm{~b}$ along the crystallographic a-axis. (c) The packing in $3 \mathrm{~b}$ viewed down the crystallographic a-axis. Colour code: $\mathrm{Re}$, dark blue; $\mathrm{Ni}, \mathrm{cyan} ; \mathrm{Br}$, orange; $\mathrm{Cl}$, green; $\mathrm{O}$, red; $\mathrm{N}$, blue; $\mathrm{C}$, grey. Hydrogen atoms are omitted for clarity. $\mathrm{CH} \cdots \pi$ interactions are indicated by blue lines. In (a) and (b) solvent molecules are removed for clarity.

Complex 4a (Fig. S12 $\dagger$ ) crystallises in the triclinic space group $P \overline{1}$ with inversion centres located on the $\mathrm{Cu}^{\mathrm{II}}$ and $\mathrm{Re}^{\mathrm{IV}}$ ions with the asymmetric unit containing one half of the $\left[\mathrm{Cu}^{\mathrm{II}}\left(\mathrm{L}^{\circ}\right)_{2}\right]^{2+}$ cation and one half of the $\left[\mathrm{Re}^{\mathrm{IV}} \mathrm{Cl}_{6}\right]^{2-}$ anion. The $\left[\mathrm{Re}^{\mathrm{IV}} \mathrm{Cl}_{6}\right]^{2-}$ anion in $\mathbf{4 a}$ is isostructural to the anions described in 1a, 2a and 3a (Tables S4, S6 and S7 $\dagger$ ) and the $\left[\mathrm{Cu}^{\mathrm{II}}\left(\mathrm{L}^{\circ}\right)_{2}\right]^{2+}$ cation is structurally similar to the cation described in 1a and 2a (Fig. 1a). The $\mathrm{Cu}^{\mathrm{II}}$ ion is six coordinate and in a pseudoJahn-Teller distorted octahedral environment, with elongation along the $\mathrm{O}-\mathrm{Cu}-\mathrm{O}$ vector. The $\mathrm{Cu}-\mathrm{N}$ bond lengths are 2.0135(18) and 2.0116(18) $\AA$, with the $\mathrm{Cu}-\mathrm{O}$ bond length of 2.3021(16) $\AA$ (Table S7 $\dagger$ ). These values are similar to those observed in a previously published complex. ${ }^{41}$ The cis angles vary between 86.31(7) and 93.69(7) ${ }^{\circ}$, and the trans angles are constrained to $180^{\circ}$. The nitroxide $\mathrm{N}-\mathrm{O}$ bond length is $1.270(3) \AA$ consistent with that of the ligand in the neutral radical form. The packing in the crystal is identical to that observed in 1a. The shortest $\mathrm{CH} \cdots \pi$ interactions between the cations are between 3.5-3.8 $\AA$, the shortest $\mathrm{Cl} \cdots \mathrm{Cl}$ distance is $4.8 \AA$, and the $\mathrm{Cl} \cdots \pi$ interactions between the $\left[\mathrm{Cu}^{\mathrm{II}}\left(\mathrm{L}^{\circ}\right)_{2}\right]^{2+}$ and $\left[\mathrm{Re}^{\mathrm{IV}} \mathrm{Cl}_{6}\right]^{2-}$ ions are $3.7 \AA$ (Fig. S12 and Table S8†).

Complex $\mathbf{4} \mathbf{b}$ crystallises in the triclinic space group $P \overline{1}$, with a structure similar to that of $4 a$. The $\left[\mathrm{Cu}^{\mathrm{II}}\left(\mathrm{L}^{*}\right)_{2}\right]^{2+}$ moiety is isostructural with the cation described in $\mathbf{4 a}$, with the geometrical parameters of the $\left[\mathrm{Re}^{\mathrm{IV}} \mathrm{Br}_{6}\right]^{2-}$ unit being the same as those present in the anion of $\mathbf{1 b}$ (Tables S4 and S7 $\dagger$ ). In the extended structure the packing of $\left[\mathrm{Cu}^{\mathrm{II}}\left(\mathrm{L}^{*}\right)_{2}\right]\left[\mathrm{Re}^{\mathrm{IV}} \mathrm{Br}_{6}\right]$ is analogous to that described in $\mathbf{1 b}$. The anions display the shortest $\mathrm{Br} \cdots \mathrm{Br}$ distance of $4.6 \AA$, with $\mathrm{CH} \cdots \pi$ interactions between cations of approximately $3.6 \AA$. The $\mathrm{Br} \cdots \pi$ interactions between the $\left[\mathrm{Cu}^{\mathrm{II}}\left(\mathrm{L}^{\circ}\right)_{2}\right]^{2+}$ cations and $\left[\mathrm{Re}^{\mathrm{IV}} \mathrm{Br}_{6}\right]^{2-}$ anions are of the order of $3.7 \AA$ (Fig. S13 and Table S8†).

\section{Magnetic studies}

The $\chi_{\mathrm{M}} T$ value for complex 1a (Fig. 3 ) at $T=300 \mathrm{~K}$ is 1.96 $\mathrm{cm}^{3} \mathrm{~mol}^{-1} \mathrm{~K}$, in the range expected with contributions of 


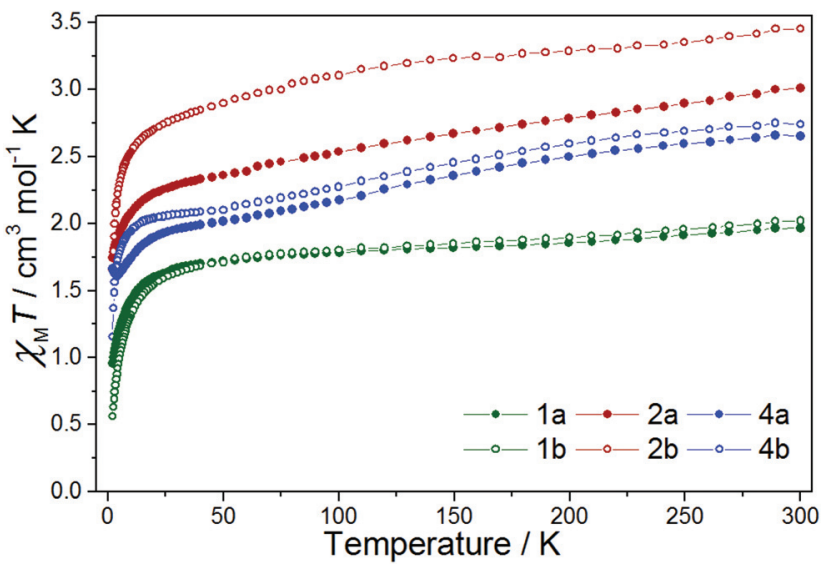

Fig. $3 \chi_{M} T$ vs. $T$ for $1 a, 1 b, 2 a, 2 b, 4 a$ and $4 b$ in the indicated temperature range, with $H=0.1 \mathrm{~T}$.

$\sim 1.52-1.69 \mathrm{~cm}^{3} \mathrm{~mol}^{-1} \mathrm{~K}$ from a magnetically isolated $\left[\mathrm{Re}^{\mathrm{IV}} \mathrm{Cl}_{6}\right]^{2-}$ anion (assuming $g=1.8-1.9$ and $S=3 / 2$ ) and the previously published value of $c a .0 .16 \mathrm{~cm}^{3} \mathrm{~mol}^{-1} \mathrm{~K}$ for the $\left[\mathrm{Fe}^{\mathrm{II}}\left(\mathrm{L}^{*}\right)_{2}\right]^{2+}$ unit. $^{42}$

The $\chi_{\mathrm{M}} T$ value decreases with decreasing temperature, first to a value of $1.82 \mathrm{~cm}^{3} \mathrm{~mol}^{-1} \mathrm{~K}$ at $T=150 \mathrm{~K}$, then more slowly to a value of $1.70 \mathrm{~cm}^{3} \mathrm{~mol}^{-1} \mathrm{~K}$ at $T=40 \mathrm{~K}$, before plunging rapidly to $0.96 \mathrm{~cm}^{3} \mathrm{~mol}^{-1} \mathrm{~K}$ at $T=2 \mathrm{~K}$. The high temperature decrease in $\chi_{\mathrm{M}} T$ is likely due to a large antiferromagnetic radical-radical coupling in the $\left[\mathrm{Fe}^{\mathrm{II}}\left(\mathrm{L}^{*}\right)_{2}\right]^{2+}$ cation, as previously reported for the species $\left[\mathrm{Fe}^{\mathrm{II}}\left(\mathrm{L}^{\circ}\right)_{2}\right]\left(\mathrm{BF}_{4}\right)_{2}$, where $J_{\text {rad-rad }}=$ $-315 \mathrm{~cm}^{-1}\left(\hat{H}=-2 J \hat{S}_{1} \hat{S}_{2}\right){ }^{42}$ The rapid low temperature decrease is attributed to the zero-field splitting ( $\mathrm{zfs}$ ) of the $\operatorname{Re}(\mathrm{Iv})$ ion, with a value of $0.96 \mathrm{~cm}^{3} \mathrm{~mol}^{-1} \mathrm{~K}$ corresponding to that expected from an isolated $\left[\mathrm{Re}^{\mathrm{IV}} \mathrm{Cl}_{6}\right]^{2-}$ ion. ${ }^{21}$ Compound $\mathbf{1 b}$ behaves in a largely similar manner, albeit with a smaller value of $\chi_{\mathrm{M}} T\left(0.56 \mathrm{~cm}^{3} \mathrm{~mol}^{-1} \mathrm{~K}\right)$ at $T=2 \mathrm{~K}^{12} \chi_{\mathrm{M}}$ versus $T$ data for $\mathbf{1 a}$ and $\mathbf{1 b}$, shown in Fig. S14, $\uparrow$ show no evidence of any significant intermolecular interactions.

For complex 2a the $\chi_{\mathrm{M}} T$ value at $T=300 \mathrm{~K}\left(3.01 \mathrm{~cm}^{3} \mathrm{~mol}^{-1} \mathrm{~K}\right)$ correlates with that expected from the sum of the previously published results for the $\left[\mathrm{Co}^{\mathrm{II}}\left(\mathrm{L}^{*}\right)_{2}\right]^{2+}$ and $\left[\mathrm{Re}^{\mathrm{IV}} \mathrm{Cl}_{6}\right]^{2-}$ ions (Fig. 3). ${ }^{21,43,45}$ In the temperature range from $T=300$ to $30 \mathrm{~K}$, the $\chi_{\mathrm{M}} T$ value decreases linearly, after which there is a sharp decline to a minimum value of $1.75 \mathrm{~cm}^{3} \mathrm{~mol}^{-1} \mathrm{~K}$ at $T=2 \mathrm{~K}$. Variable temperature structural studies, carried out on solvated samples, reveal the $\mathrm{Co}^{\mathrm{II}}$ ion to be undergoing a gradual spin-crossover transition (Fig. S7 $\uparrow$ ). It is likely, therefore, that the decrease in the $\chi_{\mathrm{M}} T$ product from $T=300$ to $30 \mathrm{~K}$ is due to a combination of a spin-crossover transition and antiferromagnetic exchange interactions between the radical ligands and the central $\mathrm{Co}^{\mathrm{II}}$ ion, as seen previously. ${ }^{43}$ The sharp low temperature downturn below $T=30 \mathrm{~K}$ is again assigned to zero-field splitting - but here from both $\mathrm{Re}^{\mathrm{IV}}$ and $\mathrm{Co}^{\mathrm{II}}$. There is no evidence of any significant intermolecular contributions to the susceptibility data at low temperatures (Fig. S15†). Complex $\mathbf{2 b}$ behaves in a similar fashion.
Crystals of complex $\mathbf{3} \mathbf{a}$ and $\mathbf{3} \mathbf{b}$ were prone to solvent loss and therefore measured in both their dried (3a(dried), $\mathbf{3 b}$ (dried)) and fully solvated (3a(solvated), $3 \mathbf{b}$ (solvated)) forms (Fig. 4). The former consisted of crystals that had been left to air dry in an open vial for up to five days, during which time they changed colour from brown to green (3a(dried)), and from brown to yellow ( $3 \mathbf{b}(\mathbf{d r i e d}))$. The fully solvated forms were measured on freshly prepared samples suspended in acetonitrile. X-ray powder diffraction data obtained on the fully solvated samples agree with the calculated patterns obtained from the relevant crystal structures, confirming phase purity (Fig. S16†). PRXD patterns of the dried samples indicate that these are in a different crystallographic phase to that present in the crystal structures (Fig. S17†). Microanalyses and IR spectra (Fig. S2 $\dagger$ ) of air dried crystals of complex 3a (dried) suggest the formulation as $\left[\mathrm{Ni}^{\mathrm{II}}\left(\mathrm{L}^{\circ}\right)\left(\mathrm{H}_{2} \mathrm{O}\right)_{3}\right]\left[\mathrm{Re}^{\mathrm{IV}} \mathrm{Cl}_{6}\right]$ and not $\left[\mathrm{Ni}^{\mathrm{II}}\left(\mathrm{L}^{\circ}\right)\left(\mathrm{CH}_{3} \mathrm{CN}\right)_{3}\right]\left[\mathrm{Re}^{\mathrm{IV}} \mathrm{Cl}_{6}\right] \cdot \mathrm{CH}_{3} \mathrm{CN}$. This is perhaps unsurprising given the labile nature of coordinated acetonitrile and the fact that the samples were left open to air before analysis. The loss of coordinated acetonitrile has been seen previously in the octahedral nickel complexes $\left[\mathrm{Tpm}^{\mathrm{Me}, \mathrm{Me}} \mathrm{Ni}\left(\mathrm{CH}_{3} \mathrm{CN}\right)_{3}\right]$ $\left(\mathrm{BF}_{4}\right)_{2}{ }^{55}$ and $\left[\mathrm{Tp}^{\mathrm{R}}{ }_{2} \mathrm{Ni}\left(\mathrm{CH}_{3} \mathrm{CN}\right)_{3}\right] \mathrm{OTf},{ }^{56}$ where $\mathrm{Tpm}^{\mathrm{Me}, \mathrm{Me}}=$ tris (3,5-dimethylpyrazol-1-yl)methane and $\mathrm{Tp}^{\mathrm{R}}{ }_{2}=$ hydrotrispyrazolyl borato with $\mathrm{R}=3,5-\mathrm{iPr}_{2}$. This is in contrast to previously
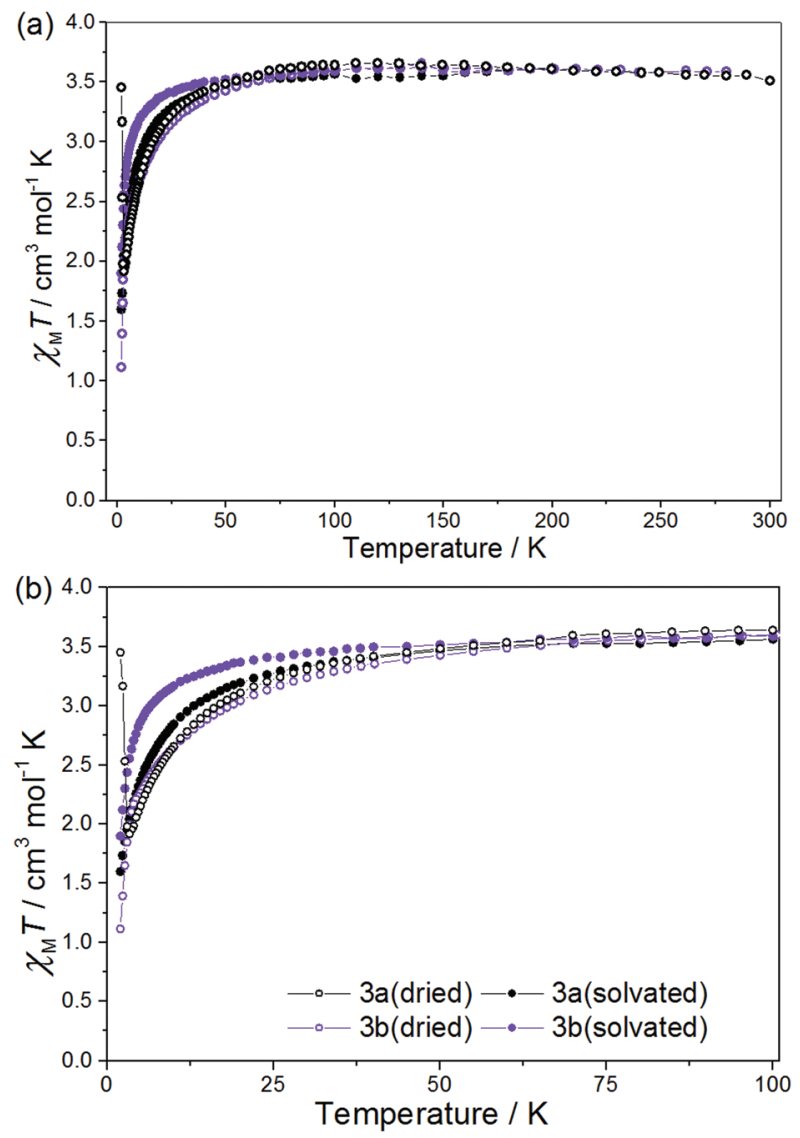

Fig. $4 \chi_{M} T$ vs. $T$ for $3 a(d r i e d), 3 a($ solvated), $3 b$ (dried) and $3 b$ (solvated) between $T=300-2 \mathrm{~K}(\mathrm{a})$ and $100-2 \mathrm{~K}(\mathrm{~b})$, in a field of $H=0.1 \mathrm{~T}$. 
published members of this family, ${ }^{42-46}$ and the majority of previously published complexes of octahedral $\mathrm{Ni}^{\mathrm{II}}$ containing three coordinated acetonitrile molecules which are stable to desolvation (Table S10 $\dagger$ ).

For $3 a$ (dried) the $\chi_{\mathrm{M}} T$ value at $T=300 \mathrm{~K}$ is $3.51 \mathrm{~cm}^{3} \mathrm{~mol}^{-1} \mathrm{~K}$, greater than the expected value for the sum of an isolated $\left[\mathrm{Re}^{\mathrm{IV}} \mathrm{Cl}_{6}\right]^{2-}$ anion (1.52-1.69 $\mathrm{cm}^{3} \mathrm{~mol}^{-1} \mathrm{~K}$ ), an octahedral $\mathrm{Ni}^{\mathrm{II}}$ ion (1.0-1.2 $\mathrm{cm}^{3} \mathrm{~mol}^{-1} \mathrm{~K}$ ) and a neutral radical ligand $\left(0.375 \mathrm{~cm}^{3} \mathrm{~mol}^{-1} \mathrm{~K}\right.$; Fig. 4). Upon cooling the $\chi_{\mathrm{M}} T$ value gradually increases to a maximum value of $3.66 \mathrm{~cm}^{3} \mathrm{~mol}^{-1} \mathrm{~K}$ at $T=$ $110 \mathrm{~K}$, before decreasing gradually to $50 \mathrm{~K}$ and then more abruptly to a minimum value of $1.92 \mathrm{~cm}^{3} \mathrm{~mol}^{-1} \mathrm{~K}$ at $T=$ $3.30 \mathrm{~K}$. The high temperature value of $\chi_{\mathrm{M}} T$ and the initial increase in its magnitude with decreasing temperature is suggestive of the presence of a ferromagnetic exchange interaction between the central $\mathrm{Ni}^{\mathrm{II}}$ ion and the coordinated radical ligand. A ferromagnetic $\mathrm{Co}^{\mathrm{II}}$-radical exchange interaction $(J=$ $63.8 \mathrm{~cm}^{-1}$ ) was reported previously in the species $\left[\mathrm{Co}^{\mathrm{II}}\left(\mathrm{L}^{\circ}\right)_{2}\right]$ $\left(\mathrm{NO}_{3}\right)_{2}$, but this is the first reported instance of any interaction between $\mathrm{a} \mathrm{Ni}^{\mathrm{II}}$ ion and the neutral radical form of the ligand used here. ${ }^{43}$ The abrupt decrease at lower temperatures is again apportioned to the $\mathrm{zfs}$ of the $\mathrm{Ni}{ }^{\mathrm{II}} / \mathrm{Re}^{\mathrm{IV}}$ ions. At the very lowest temperatures measured $(T=3.30-2.00 \mathrm{~K})$ the $\chi_{\mathrm{M}} T$ value increases once more, reaching a value of $3.45 \mathrm{~cm}^{3} \mathrm{~mol}^{-1} \mathrm{~K}$ (Fig. 4 and 5). Further measurements reveal magnetic ordering with a peak in the zero-field cooled-field-cooled (ZFC-FC) data at $T=2.4 \mathrm{~K}$ (Fig. 5b). Susceptibility measurements at $T=1.8 \mathrm{~K}$ reveal a field-dependent increase in $\chi_{\mathrm{M}}$ (Fig. 5a), and a frequency-independent peak at $T=2.7 \mathrm{~K}$ in out-of-phase ac susceptibility $\left(\chi^{\prime \prime}\right)$ measurements. Magnetisation versus field data (inset of Fig. 5a) taken at $T=1.8 \mathrm{~K}$ and $H=+3 \leftrightarrow-3$ kOe show an open hysteresis loop with a coercive field $H_{\mathrm{c}}=580$ Oe, and a remanent magnetisation $M_{\mathrm{r}}=0.21 \mu_{\mathrm{B}}$. This behaviour is indicative of spin-canting. The canting angle can be deduced from $\sin (\alpha)=M_{\mathrm{c}} / M_{\mathrm{s}}$, where $\alpha$ is the canting angle, $M_{\mathrm{c}}$ is the canting magnetisation induced by a weak field, and $M_{\mathrm{S}}$ is the magnetic saturation value. ${ }^{57,58}$ From the FC measurement $M_{\mathrm{c}}=0.181 \mu_{\mathrm{B}}$ and $M_{\mathrm{S}}=5.8 \mu_{\mathrm{B}}$, resulting in a canting angle $\alpha=$ $1.8^{\circ}$, similar to the previously published values on systems containing the $\mathrm{Re}^{\mathrm{IV}}$ ion. ${ }^{2,57,58}$ Complexes $\mathbf{3 a}$ (solvated), $\mathbf{3 b}$ (dried) (which were analysed as the hydrated analogue $\left[\mathrm{Ni}^{\mathrm{II}}\left(\mathrm{L}^{*}\right)\right.$ $\left.\left.\left(\mathrm{H}_{2} \mathrm{O}\right)_{3}\right]\left[\mathrm{Re}^{\mathrm{IV}} \mathrm{Br}_{6}\right]\right)$ and $3 \mathbf{b}$ (solvated) all behave in a similar manner to $\mathbf{3 a}$ (dried), but with no evidence of any significant intermolecular interactions/spin canting at low temperature. The origin of these differences is clearly the different packing effects/intermolecular interactions in the extended structures.

The $\chi_{\mathrm{M}} T$ value for complex $4 \mathrm{a}$ at $300 \mathrm{~K}$ is $2.66 \mathrm{~cm}^{3} \mathrm{~mol}^{-1} \mathrm{~K}$ (Fig. 3) in agreement with the previously published values for the sum of the $\left[\mathrm{Cu}^{\mathrm{II}}\left(\mathrm{L}^{\circ}\right)_{2}\right]^{2+}$ cation and the $\left[\mathrm{Re}^{\mathrm{IV}} \mathrm{Cl}_{6}\right]^{2-}$ ion (vide supra). ${ }^{21,23,41}$ As the sample is cooled, the $\chi_{\mathrm{M}} T$ value decreases gradually to $\mathrm{ca} . T=50 \mathrm{~K}$ where it plateaus at a value of $2.01 \mathrm{~cm}^{3} \mathrm{~mol}^{-1} \mathrm{~K}$. Upon further cooling the $\chi_{\mathrm{M}} T$ value decreases rapidly, reaching a minimum of $1.62 \mathrm{~cm}^{3} \mathrm{~mol}^{-1} \mathrm{~K}$ at $T=4 \mathrm{~K}$, before increasing slightly between $T=4-2 \mathrm{~K}$. The high temperature decrease stems from a substantial antiferromagnetic coupling between the radical ligands and the $\mathrm{Cu}^{\mathrm{II}}$ (a)
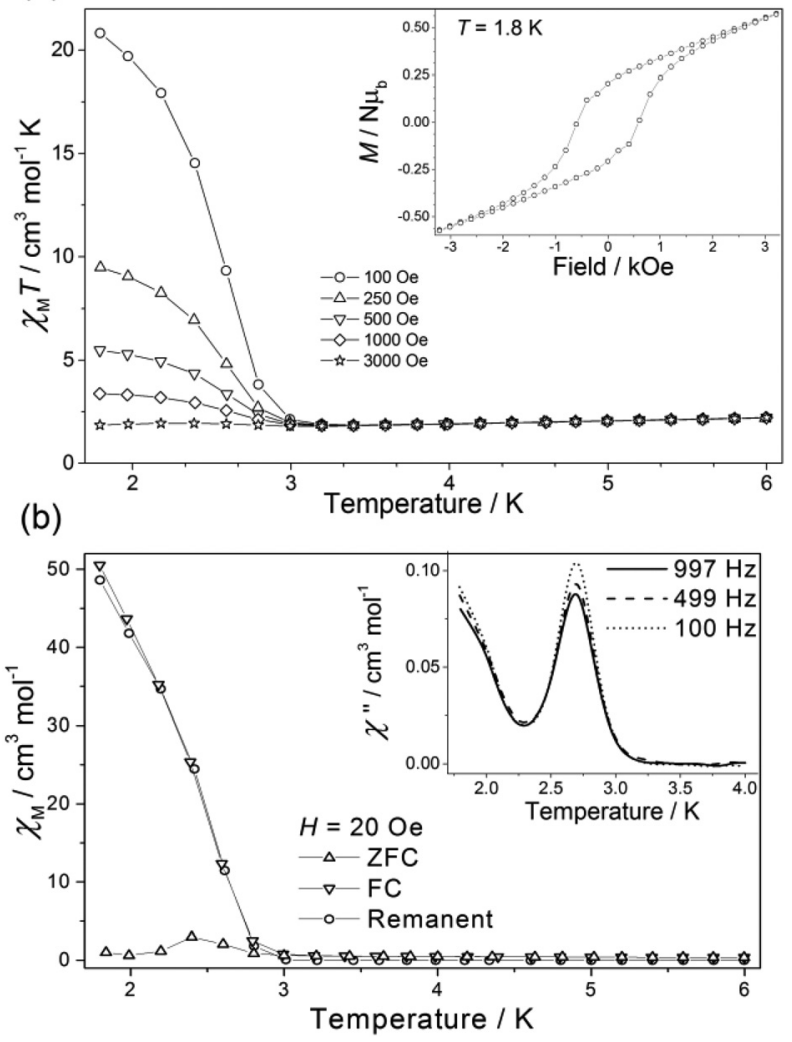

Fig. 5 (a) Susceptibility (as $\chi_{M} T$ vs. $T$ ) of $3 a$ (dried) measured in the indicated field and temperature ranges. The inset illustrates the open hysteresis loop at $T=1.8 \mathrm{~K}$. (b) Zero-field-cooled (ZFC), field-cooled (FC) and remanent susceptibility measurement of $3 a$ (dried). The inset shows the out-of-phase ac signal at three frequencies.

ion in the $\left[\mathrm{Cu}^{\mathrm{II}}\left(\mathrm{L}^{\circ}\right)_{2}\right]^{2+}$ cation; a previously reported value of $J_{\mathrm{Cu}-\mathrm{rad}}=-81.6 \mathrm{~cm}^{-1}\left(\hat{H}=-2 J \hat{S}_{1} \hat{S}_{2}\right)$ resulting in a fully populated $S=1 / 2$ state at $T=50 \mathrm{~K} .{ }^{41}$ This is corroborated by the $\chi_{\mathrm{M}} T$ value of $2.01 \mathrm{~cm}^{3} \mathrm{~mol}^{-1} \mathrm{~K}$ at $T=50 \mathrm{~K}$ for $4 \mathrm{a}$ which matches the $\chi_{\mathrm{M}} T$ value expected for an isolated $\left[\mathrm{Re}^{\mathrm{IV}} \mathrm{Cl}_{6}\right]^{2-}$ anion (1.52-1.69 $\left.\mathrm{cm}^{3} \mathrm{~mol}^{-1} \mathrm{~K}\right)$ and an isolated $S=1 / 2$ $\left[\mathrm{Cu}^{\mathrm{II}}\left(\mathrm{L}^{*}\right)_{2}\right]^{2+}$ cation $\left(0.375 \mathrm{~cm}^{3} \mathrm{~mol}^{-1} \mathrm{~K}\right)$. The behaviour of $4 \mathbf{b}$ is analogous to that of $\mathbf{4 a}$, with the only difference occurring in the very low temperature region $(T<4 \mathrm{~K})$ where the $\chi_{\mathrm{M}} T$ product of $\mathbf{4 b}$ continues to decrease with decreasing temperature. The origin of this difference may be the presence of very weak ferro/antiferromagnetic intermolecular interactions in $\mathbf{4 a} / \mathbf{4 b}$, respectively. Further studies would require collection of magnetic data at $T<2 \mathrm{~K}$, which is beyond the scope of this paper.

\section{Conclusions}

We have reported the synthesis and magnetic characterisation of a series of coordination compounds containing both the $\left[\mathrm{M}^{\mathrm{II}}\left(\mathrm{L}^{\bullet}\right)_{2}\right]^{2+}$ cation and the $\left[\mathrm{Re}^{\mathrm{IV}} \mathrm{X}_{6}\right]^{2-}$ anion, where $\mathrm{L}^{\cdot}$ is the 
aminoxyl radical chelating ligand, 4,4'-dimethyl-2,2'-di(2pyridyl)oxazolidine- $\mathrm{N}$-oxide, the first examples of salts of this cation with any 5d complex anion. Complexes 1a, 1b, 2a and 2b show antiferromagnetic metal-radical exchange interactions, with the data for $\mathbf{2 a}$ and $\mathbf{2} \mathbf{b}$ suggesting a gradual, thermally induced spin-crossover transition at the $\mathrm{Co}^{\mathrm{II}}$ centres. The $\mathrm{Ni}^{\mathrm{II}}$ containing cations in compounds $\mathbf{3} \mathbf{a}$ and $\mathbf{3 b}$ contain one tridentate neutral radical ligand and three coordinated acetonitrile molecules. Upon drying, the coordinated acetonitrile molecules dissociate and are replaced by atmospheric water. Subsequent magnetic susceptibility measurements on both dried (3a(dried), $\mathbf{3 b}$ (dried)) and solvated samples (3a(solvated), $3 \mathbf{b}$ (solvated)) revealed nickel-radical ferromagnetic exchange coupling. $3 a$ (dried) exhibits spin-canting behaviour with an ordering temperature of $T=2.7 \mathrm{~K}$ and an open hysteresis loop with a coercive field $H_{\mathrm{c}}=580 \mathrm{Oe}$, remanent magnetisation $M_{\mathrm{r}}=0.21 \mu_{\mathrm{B}}$ and a spin-canting angle, $\alpha=1.8^{\circ}$. 4a and 4b show antiferromagnetic metal-radical exchange interactions, with no significant interactions with the $\left[\mathrm{Re}^{\mathrm{IV}} \mathrm{X}_{6}\right]^{2-}$ ions in the extended structure. The synthesis of compounds 1-4 hints at the possibility of creating a very large family of magnetic salts of the type $\left[\mathrm{M}^{\mathrm{II}}\left(\mathrm{L}^{*}\right)_{2}\right]\left[\mathrm{M}^{\prime} \mathrm{X}_{6}\right]$ whereby the anionic moiety can be changed at will for a variety of species whose magnetic behaviour will depend on the structural relationship between the cation and anion.

\section{Acknowledgements}

EKB thanks the EPSRC for funding. JML thanks the Spanish Ministry of Economy and Competitiveness (MINECO) for projects CTQ2016-75068P and MDM-2015-0538 (Excellence Unit "María de Maeztu").

\section{References}

1 R. Sessoli, D. Gatteschi, A. Caneschi and M. A. Novak, Nature, 1993, 365, 141-143.

2 G. A. Craig and M. Murrie, Chem. Soc. Rev., 2015, 44, 21352147.

3 S. Demir, I.-R. Jeon, J. R. Long and T. D. Harris, Coord. Chem. Rev., 2015, 289-290, 149-176.

4 K. S. Pedersen, J. Bendix and R. Clérac, Chem. Commun., 2014, 50, 4396-4415.

5 X.-Y. Wang, C. Avendano and K. R. Dunbar, Chem. Soc. Rev., 2011, 40, 3213-3238.

6 I. Ratera and J. Veciana, Chem. Soc. Rev., 2012, 41, 303-349.

7 R. J. Blagg, L. Ungur, F. Tuna, J. Speak, P. Comar, D. Collison, W. Wernsdorfer, E. J. L. McInnes, L. F. Chibotaru and R. E. P. Winpenny, Nat. Chem., 2013, 5, 673-678.

8 M. A. Antunes, L. C. J. Pereira, I. C. Santos, M. Mazzanti, J. Marçalo and M. Almeida, Inorg. Chem., 2011, 50, 99159917.
9 K. R. Dunbar, E. J. Schelter, A. V. Palii, S. M. Ostrovsky, V. Y. Mirovitskii, J. M. Hudson, M. A. Omary, S. I. Klokishner and B. S. Tsukerblat, J. Phys. Chem. A, 2003, 107, 11102-11111.

10 J. Martínez-Lillo, D. Armentano, G. De Munno, W. Wernsdorfer, M. Julve, F. Lloret and J. Faus, J. Am. Chem. Soc., 2006, 128, 14218-14219.

11 D. Pinkowicz, H. I. Southerland, C. Avendaño, A. Prosvirin, C. Sanders, W. Wernsdorfer, K. S. Pedersen, J. Dreiser, R. Clérac, J. Nehrkorn, G. G. Simeoni, A. Schnegg, K. Holldack and K. R. Dunbar, J. Am. Chem. Soc., 2015, 137, 14406-14422.

12 J. Martinez-Lillo, J. Faus, F. Lloret and M. Julve, Coord. Chem. Rev., 2015, 289-290, 215-237.

13 S. K. Singh and G. Rajaraman, Nat. Commun., 2016, 7, 10669.

14 P. A. Reynolds, B. Moubaraki, K. S. Murray, J. W. Cable, L. M. Engelhardt and B. N. Figgis, Dalton Trans., 1997, 263-268.

15 C. M. Nelson, G. E. Boyd and W. T. Smith Jr., J. Am. Chem. Soc., 1954, 76, 348-352.

16 B. N. Figgis, J. Lewis and F. E. Mabbs, J. Chem. Soc., 1961, 3138-3145.

17 R. H. Busey and E. Sonder, J. Chem. Phys., 1962, 36, 93-97. 18 J. Martinez-Lillo, D. Armentano, G. De Munno, F. Lloret, M. Julve and J. Faus, Cryst. Growth Des., 2006, 6, 2204-2206.

19 R. Chiozzone, R. González, C. Kremer, G. De Munno, J. Cano, F. Lloret, M. Julve and J. Faus, Inorg. Chem., 1999, 38, 4745-4752.

20 J. Martínez-Lillo, D. Armentano, G. De Munno, N. Marino, F. Lloret, M. Julve and J. Faus, CrystEngComm, 2008, 10, 1284-1287.

21 R. Gonzalez, F. Romero, D. Luneau, D. Armentano, G. De Munno, C. Kremer, F. Lloret, M. Julve and J. Faus, Inorg. Chim. Acta, 2005, 358, 3995-4002.

22 R. Gonzalez, R. Chiozzone, C. Kremer, G. De Munno, F. Nicolo, F. Lloret, M. Julve and J. Faus, Inorg. Chem., 2003, 42, 2512-2518.

23 R. Gonzalez, R. Chiozzone, C. Kremer, F. Guerra, G. De Munno, F. Lloret, M. Julve and J. Faus, Inorg. Chem., 2004, 43, 3013-3019.

24 J. Martinez-Lillo, J. Cano, W. Wernsdorfer and E. K. Brechin, Chem. - Eur. J., 2015, 21, 8790-8798.

25 J. Martinez-Lillo, A. H. Pedersen, J. Faus, M. Julve and E. K. Brechin, Cryst. Growth Des., 2015, 15, 2598-2601.

26 C. J. Milios, C. P. Raptopoulou, A. Terzis, F. Lloret, R. Vicente, S. P. Perlepes and A. Escuer, Angew. Chem., Int. Ed., 2004, 43, 210-212.

27 C. J. Milios, A. Vinslava, W. Wernsdorfer, S. Moggach, S. Parsons, S. P. Perlepes, G. Christou and E. K. Brechin, J. Am. Chem. Soc., 2007, 129, 2754-2755.

28 C. J. Milios, A. Vinslava, P. A. Wood, S. Parsons, W. Wernsdorfer, G. Christou, S. P. Perlepes and E. K. Brechin, J. Am. Chem. Soc., 2007, 129, 8-9.

29 C. J. Milios, A. Vinslava, W. Wernsdorfer, A. Prescimone, P. A. Wood, S. Parsons, S. P. Perlepes, G. Christou and E. K. Brechin, J. Am. Chem. Soc., 2007, 129, 6547-6561. 
30 C. J. Milios, R. Inglis, A. Vinslava, R. Bagai, W. Wernsdorfer, S. Parsons, S. P. Perlepes, G. Christou and E. K. Brechin, J. Am. Chem. Soc., 2007, 129, 12505-12511.

31 C. J. Milios, R. Inglis, R. Bagai, W. Wernsdorfer, A. Collins, S. Moggach, S. Parsons, S. P. Perlepes, G. Christou and E. K. Brechin, Chem. Commun., 2007, 3476-3478.

32 C. J. Milios, S. Piligkos and E. K. Brechin, Dalton Trans., 2008, 1809-1817.

33 A.-R. Tomsa, J. Martinez-Lillo, Y. Li, L.-M. Chamoreau, K. Boubekeur, F. Farias, M. A. Novak, E. Cremades, E. Ruiz, A. Proust, M. Verdaguer and P. Gouzerh, Chem. Commun., 2010, 46, 5106-5108.

34 R. Inglis, C. J. Milios, L. F. Jones, S. Piligkos and E. K. Brechin, Chem. Commun., 2012, 48, 181-190.

35 A. Caneschi, D. Gatteschi and P. Rey, in Prog. Inorg. Chem, John Wiley \& Sons, Inc., 1991, pp. 331-429.

36 A. Caneschi, D. Gatteschi, R. Sessoli and P. Rey, Acc. Chem. Res., 1989, 22, 392-398.

37 A. Caneschi, D. Gatteschi, N. Lalioti, C. Sangregorio, R. Sessoli, G. Venturi, A. Vindigni, A. Rettori, M. G. Pini and M. A. Novak, Angew. Chem., Int. Ed., 2001, 40, 17601763.

38 K. Inoue and H. Iwamura, J. Am. Chem. Soc., 1994, 116, 3173-3174.

39 D. Luneau, F. M. Romero and R. Ziessel, Inorg. Chem., 1998, 37, 5078-5087.

40 K. Fegy, D. Luneau, T. Ohm, C. Paulsen and P. Rey, Angew. Chem., Int. Ed., 1998, 37, 1270-1273.

41 A. Ito, Y. Nakano, M. Urabe, K. Tanaka and M. Shiro, Eur. J. Inorg. Chem., 2006, 3359-3368.

42 I. A. Gass, C. J. Gartshore, D. W. Lupton, B. Moubaraki, A. Nafady, A. M. Bond, J. F. Boas, J. D. Cashion, C. Milsmann, K. Wieghardt and K. S. Murray, Inorg. Chem., 2011, 50, 3052-3064.
43 I. A. Gass, S. Tewary, A. Nafady, N. F. Chilton, C. J. Gartshore, M. Asadi, D. W. Lupton, B. Moubaraki, A. M. Bond, J. F. Boas, S.-X. Guo, G. Rajaraman and K. S. Murray, Inorg. Chem., 2013, 52, 7557-7572.

44 S. Tewary, I. A. Gass, K. S. Murray and G. Rajaraman, Eur. J. Inorg. Chem., 2013, 2013, 1024-1032.

45 I. A. Gass, S. Tewary, G. Rajaraman, M. Asadi, D. W. Lupton, B. Moubaraki, G. Chastanet, J.-F. Letard and K. S. Murray, Inorg. Chem., 2014, 53, 5055-5066.

46 I. A. Gass, M. Asadi, D. W. Lupton, B. Moubaraki, A. M. Bond, S.-X. Guo and K. S. Murray, Aust. J. Chem., 2014, 67, 1618-1624.

47 J. Kleinberg, Inorg. Synth, McGraw-Hill, 1963.

48 G. A. Bain and J. F. Berry, J. Chem. Educ., 2008, 85, 532-536. 49 L. J. Bourhis, O. V. Dolomanov, R. J. Gildea, J. A. K. Howard and H. Puschmann, Acta Crystallogr., Sect. A: Fundam. Crystallogr., 2015, 71, 59-75.

50 G. Sheldrick, Acta Crystallogr., Sect. A: Fundam. Crystallogr., 2008, 64, 112-122.

51 O. V. Dolomanov, L. J. Bourhis, R. J. Gildea, J. A. K. Howard and H. Puschmann, J. Appl. Crystallogr., 2009, 42, 339-341.

52 D. Armentano and J. Martinez-Lillo, Inorg. Chim. Acta, 2012, 380, 118-124.

53 J. Martinez-Lillo, Polyhedron, 2014, 67, 213-217.

54 W.-Z. Lee, H.-S. Tseng and T.-S. Kuo, Dalton Trans., 2007, 2563-2570.

55 S. Liang, H. Wang, T. Deb, J. L. Petersen, G. T. Yee and M. P. Jensen, Inorg. Chem., 2012, 51, 12707-12719.

56 K. Uehara, S. Hikichi and M. Akita, J. Chem. Soc., Dalton Trans., 2002, 3529-3538.

57 J. Martinez-Lillo, D. Armentano, G. De Munno, M. Julve, F. Lloret and J. Faus, Dalton Trans., 2013, 42, 1687-1695.

58 J. Martínez-Lillo, F. Lloret, M. Julve and J. Faus, J. Coord. Chem., 2009, 62, 92-99. 